\title{
Evaluation of Iron-based Oxygen Carrier Supported on Alumina/Titania for Charcoal Combustion through Chemical Looping Process
}

\author{
Hsuan-Chih Wu, Young Ku* \\ Department of Chemical Engineering, National Taiwan University of Science and Technology, Taipei 10607, Taiwan
}

\begin{abstract}
Hematite supported on alumina or alumina/titania was fabricated to serve as an oxygen carrier in the chemical looping combustion (CLC) of charcoal. The reduction rate of $\mathrm{Fe}_{2} \mathrm{O}_{3} / \mathrm{Al}_{2} \mathrm{O}_{3}$ and $\mathrm{Fe}_{2} \mathrm{O}_{3} / \mathrm{Al}_{2} \mathrm{O}_{3} / \mathrm{TiO}_{2}$ particles increased with the reactor inlet's $\mathrm{CO}$ concentration and displayed a slight effect from elevated operating temperatures. Applying the shrinking core model, the mass transfer coefficients $\left(k_{g}\right)$ for the reduction of $\mathrm{Fe}_{2} \mathrm{O}_{3} / \mathrm{Al}_{2} \mathrm{O}_{3}$ and $\mathrm{Fe}_{2} \mathrm{O}_{3} / \mathrm{Al}_{2} \mathrm{O}_{3} / \mathrm{TiO}_{2}$ by $\mathrm{CO}$ were found to be 0.16 and $0.22 \mathrm{~mm} \mathrm{~s}^{-1}$, respectively, and using the $\mathrm{Fe}_{2} \mathrm{O}_{3} / \mathrm{Al}_{2} \mathrm{O}_{3}$ and $\mathrm{Fe}_{2} \mathrm{O}_{3} / \mathrm{Al}_{2} \mathrm{O}_{3} / \mathrm{TiO}_{2}$ to combust charcoal resulted in carbon conversion rates of approximately $61.8 \%$ and $47.2 \%$, respectively, when the inlet steam flow rate was set to

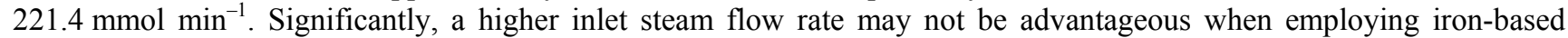
oxygen carriers. More heat was released during combustion with the $\mathrm{Fe}_{2} \mathrm{O}_{3} / \mathrm{Al}_{2} \mathrm{O}_{3}$ than with the $\mathrm{Fe}_{2} \mathrm{O}_{3} / \mathrm{Al}_{2} \mathrm{O}_{3} / \mathrm{TiO}_{2}$ due to a high flow rate for the former being used. When $\mathrm{Fe}_{2} \mathrm{O}_{3} / \mathrm{Al}_{2} \mathrm{O}_{3} / \mathrm{TiO}_{2}$ was used as the oxygen carrier, the particles, which contained a large percentage of $\mathrm{Fe}_{2} \mathrm{O}_{3}$, exhibited high reactivity to syngas $\left(\mathrm{CO} / \mathrm{H}_{2}\right)$; thus, less $\mathrm{Fe}_{2} \mathrm{O}_{3} / \mathrm{Al}_{2} \mathrm{O}_{3} / \mathrm{TiO}_{2}$ than $\mathrm{Fe}_{2} \mathrm{O}_{3} / \mathrm{Al}_{2} \mathrm{O}_{3}$ was required to combust the charcoal.
\end{abstract}

Keywords: Chemical looping process; Charcoal combustion; Hematite; Reduction kinetic; Moving bed reactor.

\section{INTRODUCTION}

Coal is the second most important energy source and distributed in many countries (WEC, 2016). Based on the Monthly Energy Review reported by the U.S. Energy Information Administration (EIA), coal contributes about $30 \%$ to electricity net generation (EIA, 2017). $\mathrm{CO}_{2}$ is a major category of greenhouse gases (GHGs) generated from traditional thermal power plants and needs reducing emission to mitigate global warming. In the past few decades, the chemical looping process (CLP) has been recognized as an innovative substitute technology for fuel conversion to implement the efficient generation of energy and the inherent separation of $\mathrm{CO}_{2}$. For chemical looping combustion (CLC) operation, the metal oxides are wrought as the oxygen source to react with fuel, as described by Eq. (1). Subsequently, the reduced particles are oxidized by air for cyclic applications, as described by Eq. (2).

$\mathrm{C}_{n} \mathrm{H}_{2 m}+(2 n+m) \mathrm{Me}_{x} \mathrm{O}_{y} \rightarrow n \mathrm{CO}_{2}+m \mathrm{H}_{2} \mathrm{O}+$

$(2 n+m) M e_{x} O_{y-1}$
$2 M e_{x} O_{y-1}+\mathrm{O}_{2(\mathrm{~g})} \leftrightarrow 2 M e_{x} O_{y}$

The Ellingham diagram illustrates the variation of oxidation Gibbs free energy $(\Delta G)$ with temperature for various compounds. Metal oxides in the Ellingham diagram, such as $\mathrm{CuO}, \mathrm{NiO}, \mathrm{Fe}_{2} \mathrm{O}_{3}, \mathrm{Mn}_{2} \mathrm{O}_{3}, \mathrm{CoO}$, and $\mathrm{CaSO}_{4}$, have strong oxidizing properties and can work as oxygen carriers for both full oxidation and partial oxidation (Fan et al., 2015; Luo et al., 2015). Zhou et al. (2014) studied the CLC of methane in a fixed bed reactor and a fluidized bed reactor using nickel oxide as the oxygen carrier and reported that the $\mathrm{CO}_{2}$ selectivity and fuel conversion of methane combustion reached above 95\%. Cao et al. (2014) demonstrated high reactivity for $\mathrm{CuO} / \mathrm{Al}_{2} \mathrm{O}_{3}$ oxygen carrier reduction with $\mathrm{H}_{2}$, and also reported that the oxygen releasing performance and thermal stability of the copper-based oxygen carrier were significantly impacted by the supporting material $\left(\mathrm{Al}_{2} \mathrm{O}_{3}\right)$. The reaction mechanisms and kinetic parameters were determined by Wang et al. (2016) using Mn-based oxygen carriers for oxygen release in a fixed bed reactor. Compared to other materials, high melting point, high mechanical strength, and low cost are major advantages have been reported for an iron-based oxygen carrier (Chiu and $\mathrm{Ku}$, 2012). Hence, hematite $\left(\mathrm{Fe}_{2} \mathrm{O}_{3}\right)$ is considered to be a reliable and appropriate oxygen carrier for CLC implementation (Luo et al., 2014a; Mattisson et al., 2004). In order to retard agglomeration and attrition of the oxygen carrier, coupling

\footnotetext{
* Corresponding author.

Tel.: +886-2-2378-5535; Fax: +886-2-2737-6644

E-mail address: ku508@mail.ntust.edu.tw
} 
of hematite with support materials, such as $\mathrm{MgAl}_{2} \mathrm{O}_{4}, \mathrm{SiO}_{2}$, $\mathrm{ZrO}_{2}, \mathrm{MgO}, \mathrm{Al}_{2} \mathrm{O}_{3}$ and $\mathrm{TiO}_{2}$, can improve the thermal and mechanical stability of oxygen carriers for CLC operation (Abad et al., 2007; Leion et al., 2008; Adánez et al., 2010; Chiu et al., 2014a; Ku et al., 2014). Ismail et al. (2014) and Sun et al. (2017) found that the addition of $\mathrm{CaO}$ and $\mathrm{CeO}_{2}$ can promote the reactivity of iron-based oxygen carrier reaction with gaseous fuel. Zafar et al. (2006) found that the $\mathrm{Fe}_{2} \mathrm{O}_{3} / \mathrm{MgAl}_{2} \mathrm{O}_{4}$ oxygen carrier showed high reactivity with methane, whereas the $\mathrm{SiO}_{2}$-supported $\mathrm{Fe}_{2} \mathrm{O}_{3}$ may not be feasible oxygen carrier due to the unreactive iron silicate was formed at high temperature. Dharanipragada et al. (2017) indicated that the activation energies of $\mathrm{Fe}_{2} \mathrm{O}_{3} / \mathrm{MgAl}_{2} \mathrm{O}_{4}$ reaction with $\mathrm{H}_{2}$ for reaction and diffusion were $104 \pm 2.3$ and $38 \pm 5 \mathrm{~kJ} \mathrm{~mol}^{-1}$, respectively. Qin et al. (2013) reported that the energy barriers of $\mathrm{Fe}_{2} \mathrm{O}_{3}$, $\mathrm{Fe}_{2} \mathrm{O}_{3} / \mathrm{Al}_{2} \mathrm{O}_{3}, \mathrm{Fe}_{2} \mathrm{O}_{3} / \mathrm{MgO}$ and $\mathrm{Fe}_{2} \mathrm{O}_{3} / \mathrm{ZrO}_{2}$ reduction with $\mathrm{CO}$ in the fuel reactor (corresponding to $\mathrm{Fe}_{2} \mathrm{O}_{3}$ to $\mathrm{FeO}$ ) was calculated as $2.59,0.99,0.98$ and 0.83 , respectively, while the energy barriers of reduced $\mathrm{Fe}_{2} \mathrm{O}_{3}, \mathrm{Fe}_{2} \mathrm{O}_{3} / \mathrm{Al}_{2} \mathrm{O}_{3}$, $\mathrm{Fe}_{2} \mathrm{O}_{3} / \mathrm{MgO}$ and $\mathrm{Fe}_{2} \mathrm{O}_{3} / \mathrm{ZrO}_{2}$ oxidization with $\mathrm{O}_{2}$ in the air reactor was determined to be $0.08,0.79,0.2$ and 1.14 , respectively. The addition of support materials decreased the energy barriers in the reduction period, whereas the energy barriers in the oxidization period are increased. Moghtaderi and Song (2010) and Monazam et al. (2013) evaluated the activation energies of $25 \mathrm{~kJ} \mathrm{~mol}^{-1}$ and $50.2-$ $64.8 \mathrm{~kJ} \mathrm{~mol}^{-1}$ for $\mathrm{Fe}_{2} \mathrm{O}_{3} / \mathrm{Al}_{2} \mathrm{O}_{3}$ and $\mathrm{Fe}_{2} \mathrm{O}_{3} / \mathrm{MgO}$ reduction with methane. Li et al. (2011) indicated the $\mathrm{O}^{2-}$ diffusivity of iron-based oxygen carrier was enhanced by using $\mathrm{TiO}_{2}$ as support because of the lower energy barrier for $\mathrm{O}^{2-}$ migration within the dense solid phase. In comparison with the above support materials, $\mathrm{Al}_{2} \mathrm{O}_{3}$ and $\mathrm{TiO}_{2}$ are a promising support material due to its high mechanical resistance, proper chemical and physical stability, and high melting point, and frequently applied to improve the thermal and mechanical stability of oxygen carriers for CLC operation. Chiu et al. (2014a) characterized the reduction mechanism of $\mathrm{Fe}_{2} \mathrm{O}_{3} / \mathrm{Al}_{2} \mathrm{O}_{3}$ oxygen carrier and observed high $\mathrm{CO}_{2}$ yields for syngas and methane combustion in a fixed bed reactor. Liu et al. (2016) indicated that $\mathrm{Fe}_{2} \mathrm{O}_{3} / \mathrm{TiO}_{2}$ oxygen carriers containing $20-30 \mathrm{wt} . \% \mathrm{TiO}_{2}$ sintered at $1100^{\circ} \mathrm{C}$ delivered high $\mathrm{CO}_{2}$ concentration and $\mathrm{H}_{2}$ conversion. However, the disintegration of $\mathrm{Fe}_{2} \mathrm{O}_{3} / \mathrm{TiO}_{2}$ oxygen carrier structure was caused by the interaction between metallic $\mathrm{Fe}$ and reduced $\mathrm{TiO}_{2-x}$ or titania species occurred during the redox cycle operation. $\mathrm{Ku}$ et al. (2017) proposed the iron cations' diffusion mechanism of $\mathrm{Fe}_{2} \mathrm{O}_{3} / \mathrm{Al}_{2} \mathrm{O}_{3}$ and $\mathrm{Fe}_{2} \mathrm{O}_{3} / \mathrm{TiO}_{2}$ pellets during reduction and oxidation operations and also indicated that the $\mathrm{Fe}_{2} \mathrm{O}_{3} / \mathrm{TiO}_{2}$ pellets exhibited approximately 2 times more attrition loss than $\mathrm{Fe}_{2} \mathrm{O}_{3} / \mathrm{Al}_{2} \mathrm{O}_{3}$ pellets. Kuo et al. (2015) found that the $\mathrm{NiFeAlO}_{4}$ oxygen carrier provided high $\mathrm{CO}$ conversion and $\mathrm{H}_{2}$ generation. Recently, more complex materials are developed and studied for chemical looping process, including perovskite-type oxides, spineltype oxides, and mixed-metal oxides (Ksepko et al., 2016). Nevertheless, most of the studies were limited to monosupport oxygen carrier. Co-support oxygen carrier has not been extensively applied for the chemical looping process.
Therefore, in this study, $\mathrm{Fe}_{2} \mathrm{O}_{3}$ supported on $\mathrm{Al}_{2} \mathrm{O}_{3}-\mathrm{TiO}_{2}$ co-support was prepared and used in evaluating its feasibility to be an oxygen carrier for CLC application.

The classification of coal can be divided into four categories, including anthracite, bituminous coal, subbituminous coal and lignite (brown coal) (IEA, 2009). Several researches have been performed in the continuous CLC facilities for coal as feedstock (Berguerand and Lyngfelt, 2008; Sozinho et al., 2012; Gu et al., 2014; Mendiara et al., 2014; Ströhle et al., 2015). Song et al. (2012) utilized the Shenhua coal and Xuzhou coal as solid fuels to evaluate the effect of char gasification efficiency on the CLC with hematite ore in a $1 \mathrm{~kW}_{\text {th }}$ fluidized bed reactor, and also reported that $\mathrm{CO}_{2}$ concentration at the fuel reactor outlet was increased with increasing char gasification efficiency, further validating that char gasification products react fast with the hematite ore. Markström et al. (2013) presented the design and operation of CLC with Colombian coal in a $100 \mathrm{~kW}_{\text {th }}$ fluidized bed reactor with ilmenite and indicated that the highest gas conversion and $\mathrm{CO}_{2}$ capture efficiency of coal combustion reached about $84.1 \%$ and $96.4-99.5 \%$ for experiments conducted at 940 $980^{\circ} \mathrm{C}$ in the fuel reactor, respectively. Furthermore, Linderholm and Schmitz (2016) reported that the highest gas conversion of nearly $87 \%$ was achieved for both Colombian coal and Calenturitas coal combustion with hematite ore, while the $\mathrm{CO}_{2}$ capture efficiencies were obtained to be $94-98 \%$.

Thon et al. (2014) applied a $25 \mathrm{~kW}_{\text {th }}$ two-stage fluidized bed reactor to investigate the CLC of lignite dust with Australian ilmenite and greater than 90 vol.\% of $\mathrm{CO}_{2}$ concentration could be achieved at the fuel reactor outlet. However, the reason is needed to be further investigated for the unconverted combustible gases appeared in the fuel reactor exhaust gas. Bayham et al. (2013) indicated that the carbon conversions were confirmed more than $90 \%$ for the combustion of both sub-bituminous coal and lignite coal using a $25 \mathrm{~kW}_{\text {th }}$ moving bed reactor operated with iron-based oxygen carriers, while $\mathrm{CO}_{2}$ concentration in the fuel reactor outlet stream was obtained to be 99.5 vol.\%. Kim et al. (2013) reported that carbon conversion for subbituminous coal and metallurgical coke combustion were found to be $97 \%$ and $81 \%$. The carbon conversion for metallurgical coke combustion was lower than that for sub-bituminous coal combustion due to the reactivity of metallurgical coke was less than sub-bituminous coal. Hence, longer residence time was required for complete conversion of metallurgical coke. In addition, high $\mathrm{CO}_{2}$ purity ( $\left.>99 \%\right)$ was obtained for both solid fuel combustion, further indicating that the counter-current moving-bed configuration for the fuel reactor is more effective in fully converting fuels to $\mathrm{CO}_{2}$ and $\mathrm{H}_{2} \mathrm{O}$ as compared to the fluidized-bed system. Biomass is considered to be a promising alternative resource for partial replacement of coal to generate sustainable energy in the future. In recent years, several biomasses have been developed and applied for chemical looping technology (Shen et al., 2009; Gu et al., 2011; Mendiara et al., 2013). Charcoal is a promising solid fuel due to its lower moisture content, higher calorific value, 
lower tendency to biodegradation, and easy to pulverize like coal (Gucho et al., 2015; Strandberg et al., 2015). Wu and $\mathrm{Ku}$ (2016) indicated that the maximum fuel conversion and oxygen carrier conversion for chemical looping gasification (CLG) of charcoal with $\mathrm{Fe}_{2} \mathrm{O}_{3} / \mathrm{Al}_{2} \mathrm{O}_{3}$ oxygen carrier were found to be $11.5 \%$ and $38.3 \%$, respectively, and also reported that more syngas $\left(\mathrm{CO} / \mathrm{H}_{2}\right)$ were generated for charcoal gasification conducted in the moving bed reactor operated with higher oxygen carrier-to-fuel ratios.

In this study, alumina/titania-supported $\mathrm{Fe}_{2} \mathrm{O}_{3}$ oxygen carrier was fabricated to investigate its reactivity with $\mathrm{CO}$ by comparing to the $\mathrm{Al}_{2} \mathrm{O}_{3}$ supported $\mathrm{Fe}_{2} \mathrm{O}_{3}$ oxygen carrier. In order to understand the kinetics of the reduction with $\mathrm{CO}$, the influences of various experimental parameters on the reduction rate of $\mathrm{Fe}_{2} \mathrm{O}_{3} / \mathrm{Al}_{2} \mathrm{O}_{3}$ or $\mathrm{Fe}_{2} \mathrm{O}_{3} / \mathrm{Al}_{2} \mathrm{O}_{3} / \mathrm{TiO}_{2}$ oxygen carriers in a fixed bed reactor were discussed and expressed using a shrinking core model (SCM). Furthermore, the present study was also aimed at applying the chemical looping process using the $\mathrm{Fe}_{2} \mathrm{O}_{3} / \mathrm{Al}_{2} \mathrm{O}_{3}$ and $\mathrm{Fe}_{2} \mathrm{O}_{3} / \mathrm{Al}_{2} \mathrm{O}_{3} / \mathrm{TiO}_{2}$ oxygen carriers to combust charcoal. Carbon conversion and oxygen carrier conversion were determined from the gaseous composition at the moving bed reactor exhaust. The crystalline phases of the reduced oxygen carrier were identified for the samples drawn out from the reactor.

\section{EXPERIMENTAL}

\section{Oxygen Carriers}

Hematite (99.9\% $\mathrm{Fe}_{2} \mathrm{O}_{3}$; China Steel Corp.) particles were dispersed in deionized water as $\mathrm{Fe}_{2} \mathrm{O}_{3}$ slurry. Alumina (99\% $\mathrm{Al}_{2} \mathrm{O}_{3}$; Chin Jung Trading Co.), utilized as a support material, was added into the $\mathrm{Fe}_{2} \mathrm{O}_{3}$ slurry solution to enhance the mechanical strength of $\mathrm{Fe}_{2} \mathrm{O}_{3} / \mathrm{Al}_{2} \mathrm{O}_{3}$ particles. The mixed solution was stirred vigorously for $10 \mathrm{~min}$ and dried at $130^{\circ} \mathrm{C}$. The cakes were then pulverized and screened their particle sizes from 1.2 to $1.4 \mathrm{~mm}$. Finally, the particles were calcined in air at $1300^{\circ} \mathrm{C}$ for $2 \mathrm{~h}$. For the preparation of $\mathrm{Fe}_{2} \mathrm{O}_{3} / \mathrm{Al}_{2} \mathrm{O}_{3} / \mathrm{TiO}_{2}$ particles, a predetermined amount of titania $\left(95.5 \% \mathrm{TiO}_{2}\right.$; Unique Enterprise Co.) was added into the slurry solution containing $\mathrm{Fe}_{2} \mathrm{O}_{3}$ and $\mathrm{Al}_{2} \mathrm{O}_{3}$. The $\mathrm{Fe}_{2} \mathrm{O}_{3} / \mathrm{Al}_{2} \mathrm{O}_{3} / \mathrm{TiO}_{2}$ particle was thereafter fabricated by mechanical mixing described in the above section. The prepared $\mathrm{Fe}_{2} \mathrm{O}_{3} / \mathrm{Al}_{2} \mathrm{O}_{3} / \mathrm{TiO}_{2}$ particles were then put in a muffle furnace and calcined isothermally at $1200^{\circ} \mathrm{C}$ for $2 \mathrm{~h}$. The weight percentage for $\mathrm{Fe}_{2} \mathrm{O}_{3} / \mathrm{Al}_{2} \mathrm{O}_{3}$ and $\mathrm{Fe}_{2} \mathrm{O}_{3} / \mathrm{Al}_{2} \mathrm{O}_{3} / \mathrm{TiO}_{2}$ particles were determined to be $60 / 40$ and 70/20/10. Crush strength and attrition of prepared particles were measured by a texture machine (TA.XTPlus) and an attrition analyzer following ASTM methods D405896. The true density, particle density and bulk density of prepared oxygen carriers were determined by Eqs. (3) and (4), respectively, similar defines and results were reported by previous researchers (Markström and Lyngfelt, 2012):

$\rho_{p}=(1-\varphi) \rho_{t}$

$\rho_{b}=(1-\varepsilon) \rho_{p}$

where $\rho_{t}$ is the true density of the oxygen carrier without the pores which presented in the oxygen carrier; $\rho_{p}$ is the particle density of the oxygen carrier including the pores, which was measured by the Archimedes method; $\rho_{b}$ is the bulk density of the oxygen carrier; $\varphi$ is $49.13 \%$ and $59.60 \%$ as the porosity of prepared $\mathrm{Fe}_{2} \mathrm{O}_{3} / \mathrm{Al}_{2} \mathrm{O}_{3}$ and $\mathrm{Fe}_{2} \mathrm{O}_{3} / \mathrm{Al}_{2} \mathrm{O}_{3} / \mathrm{TiO}_{2}$, respectively; $\varepsilon$ is the fraction of void contained in the packed $\mathrm{Fe}_{2} \mathrm{O}_{3} / \mathrm{Al}_{2} \mathrm{O}_{3}$ and $\mathrm{Fe}_{2} \mathrm{O}_{3} / \mathrm{Al}_{2} \mathrm{O}_{3} / \mathrm{TiO}_{2}$ oxygen carriers, which were determined to be $41.61 \%$ and $40.17 \%$, respectively. The main physicochemical properties of both oxygen carriers are shown in Table 1. Firck et al. (2016) and $\mathrm{Ku}$ et al. (2017) illustrated that the crushing strength of oxygen carriers is enhanced with increasing calcination temperature, hence, less crushing strength of $\mathrm{Fe}_{2} \mathrm{O}_{3} / \mathrm{Al}_{2} \mathrm{O}_{3} / \mathrm{TiO}_{2}$ oxygen carriers are obtained may be ascribed to the $\mathrm{Fe}_{2} \mathrm{O}_{3} / \mathrm{Al}_{2} \mathrm{O}_{3} / \mathrm{TiO}_{2}$ oxygen carriers calcined at the lower calcination temperature. Breault et al. (2016) indicated that the specific surface area becomes smaller, while the grain size and porosity become larger because the growth of larger grain promoted by high calcination temperature. The physical properties of the iron-based oxygen carriers reported by previous studies were similar to the results of this study that the specific surface areas were obtained to be in the range of $9.06 \mathrm{~cm}^{2} \mathrm{~s}^{-1}$ to $18 \mathrm{~m}^{2} \mathrm{~s}^{-1}$ (Gao et al., 2016; Huang et al., 2016; Ksepko et al., 2017). Huang et al. (2016) indicated that the decline of iron-based oxygen carrier reactivity is generally major caused by the specific surface area of oxygen carrier is decreased. However, the satisfactory reactivity of iron ore is observed for experiments carried out with low specific surface areas of particles. The reason is due to the release of lattice oxygen in the oxygen carrier was suggested to be a

Table 1. Main physicochemical properties of the iron-based oxygen carriers.

\begin{tabular}{llll}
\hline Parameters & Unit & $\mathrm{Fe}_{2} \mathrm{O}_{3} / \mathrm{Al}_{2} \mathrm{O}_{3}$ & $\mathrm{Fe}_{2} \mathrm{O}_{3} / \mathrm{Al}_{2} \mathrm{O}_{3} / \mathrm{TiO}_{2}$ \\
\hline $\mathrm{Fe}_{2} \mathrm{O}_{3}$ fraction & $\mathrm{wt} . \%$ & 60 & 70 \\
Particle size & $\mathrm{mm}$ & $1.2-1.4$ & $1.2-1.4$ \\
True density, $\rho_{t}$ & $\mathrm{~kg} \mathrm{~m}^{-3}$ & 4673 & 4795 \\
Particle density, $\rho_{p}$ & $\mathrm{~kg} \mathrm{~m}^{-3}$ & 2377 & 1937 \\
Bulk density, $\rho_{b}$ & $\mathrm{~kg} \mathrm{~m}$ & 1388 & 1159 \\
Porosity & $\%$ & 49.13 & 59.60 \\
Fraction void & $\%$ & 41.61 & 40.17 \\
Crushing strength & $\mathrm{N}$ & 30.53 & 10.25 \\
Attrition & $\%$ & 4.01 & 16.83 \\
Specific surface area, BET & $\mathrm{m}^{2} \mathrm{gg}^{-1}$ & 0.61 & 0.64 \\
\hline
\end{tabular}


nucleation and nuclei growth process, thus the reactivity of oxygen carrier is not individually influenced by the surface structure of the particles (Huang et al., 2016). Additionally, Ksepko et al. (2017) illustrated that the reactivity and oxygen transfer capacity of the calcined Sinai ore cannot be ascribed only to the small surface area of particles, while the bulk diffusion is considered to be contributed to the reaction kinetics. As mentioned above, the surface area is a key governing factor for evaluating the basic properties of the oxygen carrier, which also may influence the reaction kinetics of the oxygen carrier with fuel gas.

\section{Solid Fuel}

Charcoal was applied as the solid fuel for studying the reaction behavior of solid fuels with oxygen carrier in a moving bed reactor. The commercial grade charcoal used in this study was purchased from Puguang Co., Ltd. and all experimental charcoal particles were pulverized and sieved for size between $1.2 \mathrm{~mm}$ and $1.4 \mathrm{~mm}$. Thermogravimetric analyzer (TGA; STA 449 F3 Jupiter; Netzsch) was utilized to investigate the proximate analysis of charcoal up to $700^{\circ} \mathrm{C}$ with a heating rate of $20^{\circ} \mathrm{C} \mathrm{m^{-1 }}$. The elemental analyzer (vario EL III; Elementar) was used to identify the elemental contents of $\mathrm{C}, \mathrm{H}, \mathrm{O}, \mathrm{N}$, and $\mathrm{S}$. The fuel characteristics of the charcoal obtained based on the experimental results are listed in Table 2.

\section{Fixed Bed Reactor System}

Experiments were carried out in a cylindrical stainless steel $310 \mathrm{~S}$ column of $200 \mathrm{~mm}$ height and $25.4 \mathrm{~mm}$ inner diameter, which was kept isothermal at the desired temperature, ranging from 875 to $925^{\circ} \mathrm{C}$. A porous plate was installed inside the reactor to support the predetermined amount of prepared $\mathrm{Fe}_{2} \mathrm{O}_{3} / \mathrm{Al}_{2} \mathrm{O}_{3}$ or $\mathrm{Fe}_{2} \mathrm{O}_{3} / \mathrm{Al}_{2} \mathrm{O}_{3} / \mathrm{TiO}_{2}$ particles. For reduction experiments, carbon monoxide was introducing into the reactor at a flowrate of $1 \mathrm{~L} \mathrm{~min}^{-1}$ at different concentrations, ranging from 5 to $20 \%$. After reduction, the nitrogen gas flowed to the reactor until the concentration of reducing gas in the reactor was removed. The reduced particles were subsequently oxidized for $30 \mathrm{~min}$ at an air flow rate of $1 \mathrm{~L} \mathrm{~min}^{-1}$. The discharged streams were sampled at predetermined time intervals and measuring the concentration of gaseous product by a nondispersive infrared sensor (NDIR; Model 6000i Series; Molecular Analysis).

\section{Moving Bed Reactor System}

Fig. 1 shows the reaction system employed in this research contained an annular dual-tube moving bed reactor (ADMBR) made entirely of stainless steel 310S (outlet diameter: $76.20 \mathrm{~mm}$ ) as depicted in our previous research (Wu et al., 2015). The operating temperature of the reactor was maintained at $850-900^{\circ} \mathrm{C}$ by a PID-controlled electric heating element. The flow rate of charcoal throughout the experiment was kept at $1.05 \mathrm{~g} \mathrm{~min}^{-1}$. Steam molar flow rates were maintained constant at the desired rate with the $\mathrm{N}_{2}$ flow rate of $2.2 \mathrm{~L} \mathrm{~min}^{-1}$. Before starting the CLC experiments, the ADMBR was filled with the $\mathrm{Fe}_{2} \mathrm{O}_{3} / \mathrm{Al}_{2} \mathrm{O}_{3}$ particles $(3.0 \mathrm{~kg})$ or $\mathrm{Fe}_{2} \mathrm{O}_{3} / \mathrm{Al}_{2} \mathrm{O}_{3} / \mathrm{TiO}_{2}$ particles $(2.5 \mathrm{~kg})$ of a known amount. Subsequently, the $\mathrm{Fe}_{2} \mathrm{O}_{3} / \mathrm{Al}_{2} \mathrm{O}_{3}$ and $\mathrm{Fe}_{2} \mathrm{O}_{3} / \mathrm{Al}_{2} \mathrm{O}_{3} / \mathrm{TiO}_{2}$ feeding rate were fixed at $21.79 \mathrm{~g} \mathrm{~min}^{-1}$ and $7.55 \mathrm{~g} \mathrm{~min}^{-1}$, respectively. For experiments conducted under different conditions, samples of gaseous products were collected at predetermined time intervals from the ADMBR. The screw conveyor was used to draw out the solid samples and residues from the bottom of the ADMBR. All of the solid products were then oxidized at $600^{\circ} \mathrm{C}$ for $12 \mathrm{~h}$ in a muffle furnace. Here, the oxygen carrier particles were separated manually from the ash. A CLC system usually consists of a fuel reactor, an air reactor, and a cyclone. In the whole CLC system, smaller ash is relatively easier to be separated from the reactor through the cyclone. An NDIR sensor (Model 6000i Series; Molecular Analysis) was used for analyzing the gaseous product concentrations in the discharged streams. The concentrations of hydrogen in the effluent streams were determined with a China Chromatography Model 2000 gas chromatograph (GC) equipped with a thermal conductivity detector.

\section{RESULTS AND DISCUSSION}

\section{Kinetic Parameter Determination}

The mechanisms of gaseous and solid fuel combustion with oxygen carrier have been proposed by previous studies (Adánez et al., 2012; Chiu and $\mathrm{Ku}, 2012$ ) and are illustrated in Fig. 2. Gaseous fuel can directly react with the oxygen carrier to form $\mathrm{CO}_{2}$ and $\mathrm{H}_{2} \mathrm{O}$, while the chemical reaction of solid fuel with an oxygen carrier takes place in two steps. The combustible gases generated during the solid fuel gasification, and then oxygen carrier was reduced by the gasified syngas $\left(\mathrm{CO} / \mathrm{H}_{2}\right)$. Hence, the kinetic study of solid fuel gasification and oxygen carrier reduction should be simultaneously considered for CLC of solid fuel in order to preliminarily assess the performance of the prepared oxygen carrier for solid fuel combustion. In this study, carbon monoxide (CO) used as reducing gas to determine the reduction kinetic parameters of $\mathrm{Fe}$-based oxygen carriers.

The iron-based oxygen carriers were fully reduced for carbon monoxide combustion as described by Eq. (5) (Fan, 2010):

$$
\mathrm{CO}+\frac{1}{3} \mathrm{Fe}_{2} \mathrm{O}_{3} \leftrightarrow \frac{2}{3} \mathrm{Fe}+\mathrm{CO}_{2}
$$

Table 2. Proximate and ultimate analysis of charcoal.

\begin{tabular}{|c|c|c|c|c|c|c|c|c|c|c|}
\hline \multirow{2}{*}{ Fuel } & \multicolumn{4}{|c|}{ Proximate analysis (wt.\%) } & \multicolumn{5}{|c|}{ Ultimate analysis (wt.\%) } & \multirow{2}{*}{$\begin{array}{l}\mathrm{HHV} \\
\left(\mathrm{MJ} \mathrm{kg}^{-1}\right)\end{array}$} \\
\hline & $\mathrm{M}$ & VM & $\mathrm{FC}$ & AW & $\mathrm{N}$ & $\mathrm{C}$ & $\mathrm{H}$ & $\mathrm{O}$ & $\mathrm{S}$ & \\
\hline Charcoal & 1.18 & 0.55 & 90.79 & 2.48 & 0.88 & 83.41 & 2.11 & 2.69 & 0.08 & 31.32 \\
\hline
\end{tabular}

M: Moisture; VM: Volatile Material; FC: Fixed Carbon; A: Ash; HHV: Higher Heating Value. 


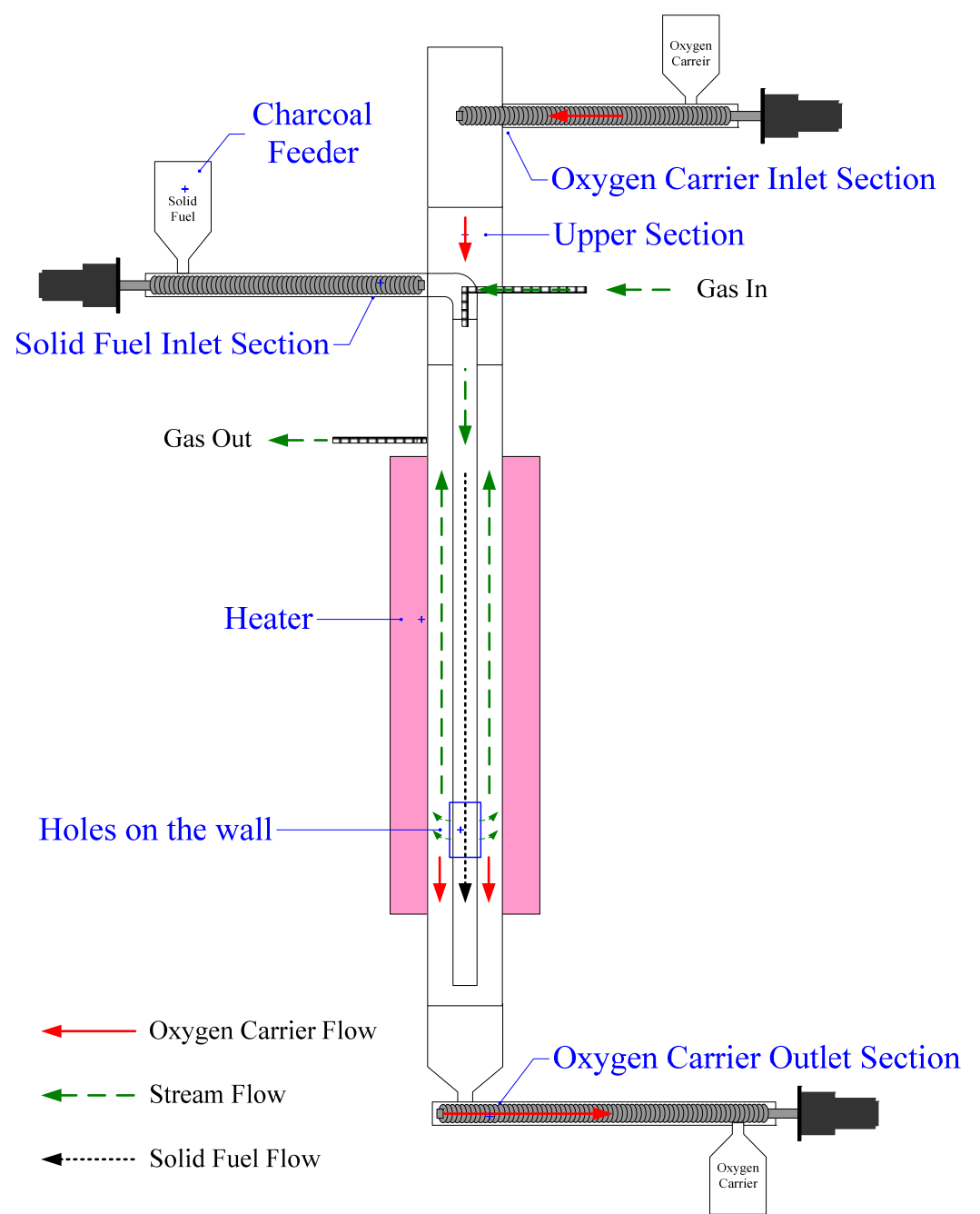

Fig. 1. Moving bed reactor system experimental setup.

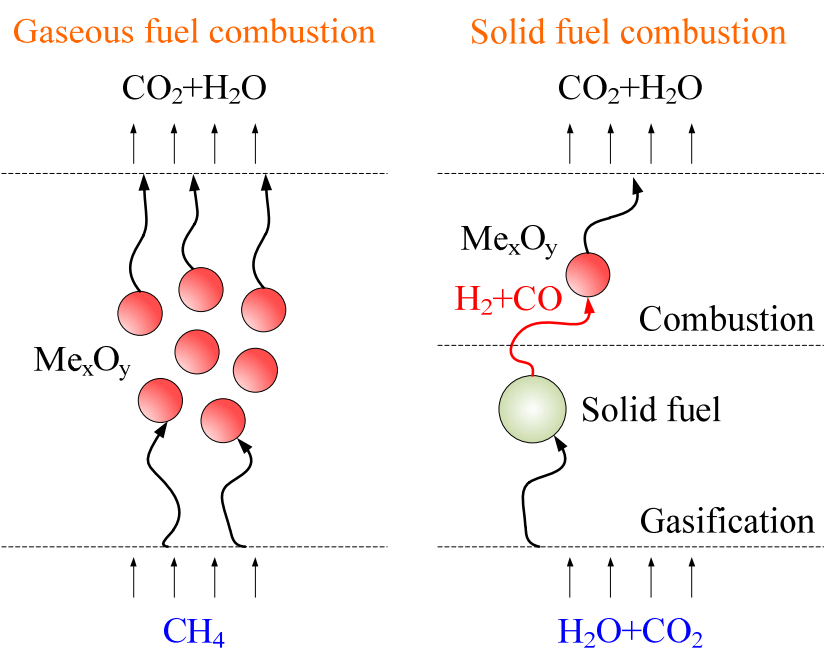

Fig. 2. Reaction mechanisms for gaseous and solid fuel combustion with oxygen carrier by CLC.

Based on the mass balances of oxygen and carbon, the reduction conversion of iron-based oxygen carriers for carbon monoxide combustion is determined as:

$$
X_{r e d}=\frac{\int\left(F_{\mathrm{CO}_{2}}+F_{\mathrm{CO}}-F_{C O, \text { in }}\right) d t}{\left(\frac{x_{\mathrm{Fe}_{2} \mathrm{O}_{3}} \cdot m_{\mathrm{OC}}}{M_{\mathrm{Fe}_{2} \mathrm{O}_{3}}}\right)}
$$

where $F_{C O \text {,in }}$ denotes the initial flow rate $\left(\mathrm{mmol} \mathrm{min}^{-1}\right)$ of

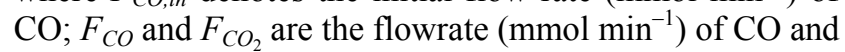
$\mathrm{CO}_{2}$ in the effluent stream after time $t ; M_{\mathrm{Fe}_{2} \mathrm{O}_{3}}$ denotes the molar mass of $\mathrm{Fe}_{2} \mathrm{O}_{3} ; m_{O C}$ denotes the packing weight (g) of iron-based particles; $x_{\mathrm{Fe}_{2} \mathrm{O}_{3}}$ denotes the $\mathrm{Fe}_{2} \mathrm{O}_{3}$ content of the iron-based particles. Fig. 3 shows the effect of operating temperature on the reduction of iron-based oxygen carriers with $\mathrm{CO}$. The reduction conversions of $\mathrm{Fe}_{2} \mathrm{O}_{3} / \mathrm{Al}_{2} \mathrm{O}_{3}$ oxygen carriers for $\mathrm{CO}$ combustion were increased with operation time and were slightly influenced with increasing operating temperatures. However, $X_{\text {red }}$ for $\mathrm{CLC}$ of $\mathrm{CO}$ with $\mathrm{Fe}_{2} \mathrm{O}_{3} / \mathrm{Al}_{2} \mathrm{O}_{3} / \mathrm{TiO}_{2}$ particles was enhanced for experiments conducted with longer operation time, and gradually maintained to about $33 \%$, while reduction of $\mathrm{Fe}_{2} \mathrm{O}_{3} / \mathrm{Al}_{2} \mathrm{O}_{3} / \mathrm{TiO}_{2}$ particles was similar for experiments carried out at operating temperature ranged from 875 to $925^{\circ} \mathrm{C}$. Fig. 4 exhibits the effect of inlet carbon monoxide 


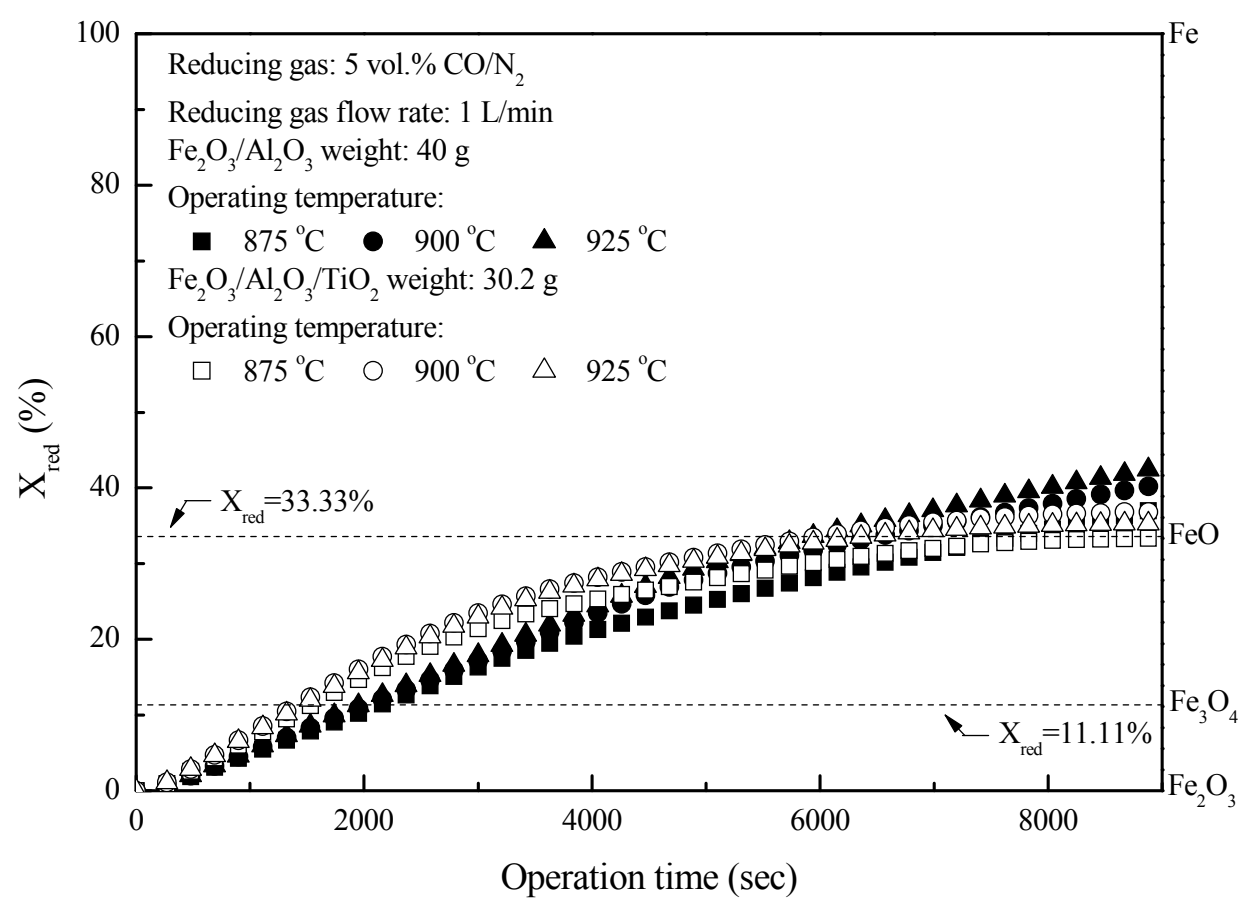

Fig. 3. Effect of operating temperature on the reduction of $\mathrm{Fe}_{2} \mathrm{O}_{3} / \mathrm{Al}_{2} \mathrm{O}_{3}$ and $\mathrm{Fe}_{2} \mathrm{O}_{3} / \mathrm{Al}_{2} \mathrm{O}_{3} / \mathrm{TiO}_{2}$ with $\mathrm{CO}$ in the fixed bed.

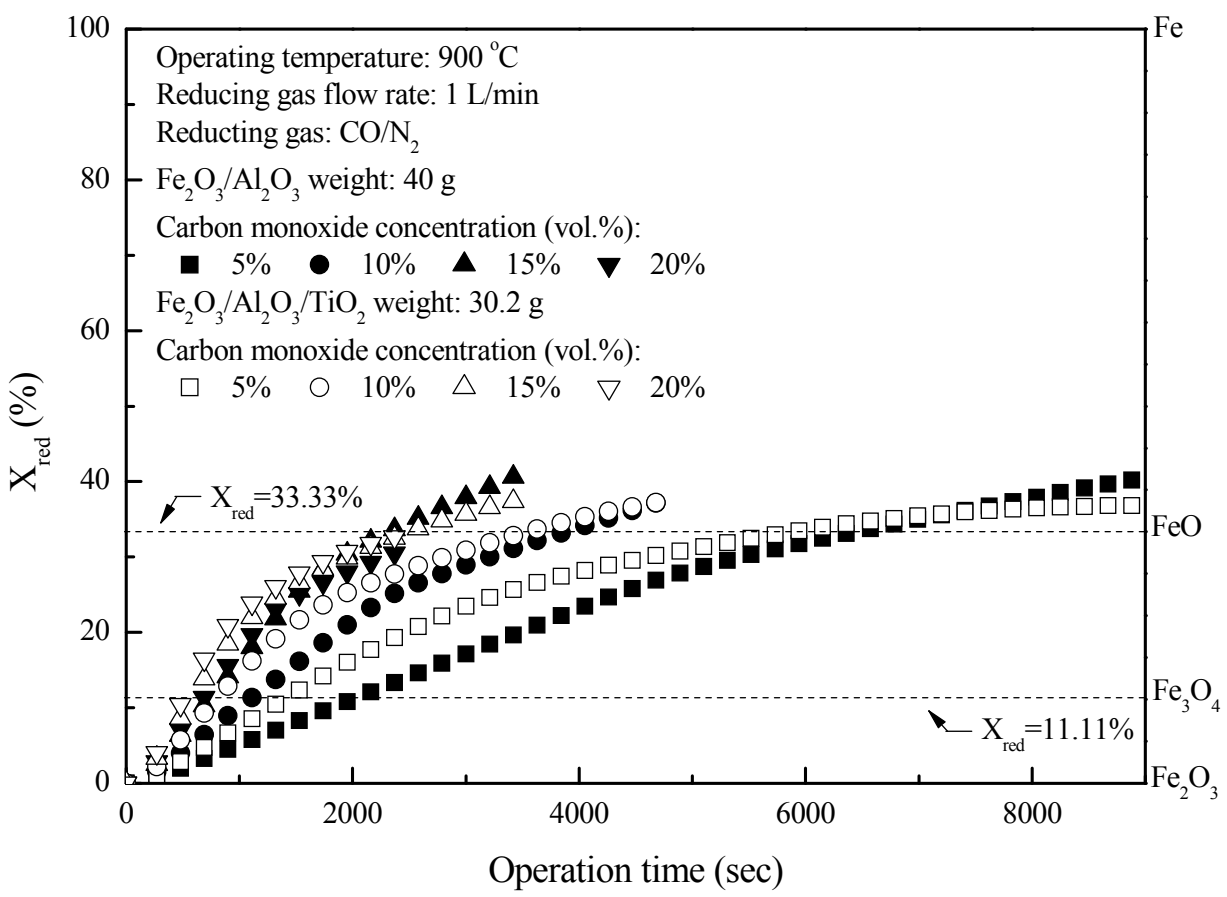

Fig. 4. Effect of inlet $\mathrm{CO}$ concentrations on the reduction of $\mathrm{Fe}_{2} \mathrm{O}_{3} / \mathrm{Al}_{2} \mathrm{O}_{3}$ and $\mathrm{Fe}_{2} \mathrm{O}_{3} / \mathrm{Al}_{2} \mathrm{O}_{3} / \mathrm{TiO}_{2}$ with $\mathrm{CO}$ in the fixed bed.

concentrations on the CLC of $\mathrm{CO}$ by iron-based oxygen carriers. The conversions of $\mathrm{Fe}_{2} \mathrm{O}_{3} / \mathrm{Al}_{2} \mathrm{O}_{3}$ and $\mathrm{Fe}_{2} \mathrm{O}_{3} / \mathrm{Al}_{2} \mathrm{O}_{3} / \mathrm{TiO}_{2}$ reduction were increased for experiments conducted with greater inlet $\mathrm{CO}$ concentrations, possibly because of the existence of more carbon monoxide molecules. More carbon monoxide molecules are more ready to react with $\mathrm{Fe}_{2} \mathrm{O}_{3}$ contained in the iron-based oxygen carriers to create carbon dioxide.
In this study, the temporal reduction behavior of ironbased oxygen carrier was described by a shrinking core model (SCM). The similar applications were exercised in the previous researches (Abad et al., 2007; Cabello et al., 2014; Abad et al., 2015).

$$
1-X_{r e d}=\left(\frac{r}{R}\right)^{3}
$$




$$
\begin{aligned}
& t=\tau_{g f} X_{r e d}+\tau_{p l}\left[1-3\left(1-X_{r e d}\right)^{\frac{2}{3}}+2\left(1-X_{r e d}\right)\right] \\
& \tau_{g f}=\frac{1000 \cdot x_{\mathrm{Fe}_{2} \mathrm{O}_{3}} \cdot \rho_{P} \cdot R}{3 \cdot b \cdot C_{A g} \cdot M_{F e_{2} O_{3}} \cdot k_{g}} \\
& \tau_{p l}=\frac{1000 \cdot x_{\mathrm{Fe}_{2} \mathrm{O}_{3}} \cdot \rho_{P} \cdot R^{2}}{6 \cdot b \cdot C_{A g} \cdot M_{F e_{2} O_{3}} \cdot D_{e}} \\
& D_{e}=D_{p l, 0} \cdot e^{-\frac{E a_{p l}}{R_{g} T}-k_{d} X_{r e d}} \\
& k_{d}=k_{d, 0} \cdot e^{-\frac{E a_{d}}{R_{g} T}}
\end{aligned}
$$

where $R$ and $r$ are the radius $(\mathrm{m})$ of the fresh particle and the unreacted core; $\tau_{g f}$ and $\tau_{p l}$ are the time (s) required for complete conversion of the oxygen carrier when the reaction is controlled by the gas-film diffusion and the product layer diffusion; $C_{A g}$ is the inlet molar concentration $\left(\mathrm{mol} \mathrm{m}^{-3}\right)$ of the gaseous fuel; $b$ denotes the stoichiometric coefficient, which is determined to be $1 / 3$ by Eq. (5); $k_{g}$ denotes the mass transfer coefficient $\left(\mathrm{m} \mathrm{s}^{-1}\right)$ between gaseous fuel and oxygen carriers; $D_{e}$ denotes the effective diffusion coefficient $\left(\mathrm{m}^{2} \mathrm{~s}^{-1}\right)$ of gaseous fuel in the product layer; $D_{p l, 0}\left(\mathrm{~m}^{2} \mathrm{~s}^{-1}\right)$ and $E a_{p l}\left(\mathrm{~kJ} \mathrm{~mol}^{-1}\right)$ are the pre-exponential factor and activation energy for the product layer diffusion reaction; $k_{d}, k_{d, 0}$ and $E a_{d}\left(\mathrm{~kJ} \mathrm{~mol}^{-1}\right)$ are the decay constant, preexponential factor and activation energy for the product layer diffusivity; $R_{g}$ denotes the ideal gas constant; $T(\mathrm{~K})$ denotes the operation temperature.

The reduction kinetics of $\mathrm{Fe}_{2} \mathrm{O}_{3} / \mathrm{Al}_{2} \mathrm{O}_{3}$ and $\mathrm{Fe}_{2} \mathrm{O}_{3} / \mathrm{Al}_{2} \mathrm{O}_{3} / \mathrm{TiO}_{2}$ with carbon monoxide were regressed and calculated by the shrinking core model (SCM), as described in Eqs. (7)-(12). After fitting the conversion curves, the kinetic parameters were summarized in Table 3. The mass transfer coefficient $\left(k_{g}\right)$ of around $0.16 \mathrm{~mm} \mathrm{~s}^{-1}$ was calculated for the reduction of $\mathrm{Fe}_{2} \mathrm{O}_{3} / \mathrm{Al}_{2} \mathrm{O}_{3}$ with carbon monoxide, while the $k_{g}$ of $\mathrm{Fe}_{2} \mathrm{O}_{3} / \mathrm{Al}_{2} \mathrm{O}_{3} / \mathrm{TiO}_{2}$ for carbon monoxide combustion reached $0.22 \mathrm{~mm} \mathrm{~s}^{-1}$, indicating that the reaction rate of carbon monoxide for $\mathrm{Fe}_{2} \mathrm{O}_{3} / \mathrm{Al}_{2} \mathrm{O}_{3} / \mathrm{TiO}_{2}$ reduction was faster than that for $\mathrm{Fe}_{2} \mathrm{O}_{3} / \mathrm{Al}_{2} \mathrm{O}_{3}$ reduction. Less $D_{p l, 0}$ was obtained for experiments with $\mathrm{Fe}_{2} \mathrm{O}_{3} / \mathrm{Al}_{2} \mathrm{O}_{3}$ oxygen carriers than those with $\mathrm{Fe}_{2} \mathrm{O}_{3} / \mathrm{Al}_{2} \mathrm{O}_{3} / \mathrm{TiO}_{2}$ oxygen carriers, explicitly demonstrating that the carbon monoxide more easily diffused through the product layer of $\mathrm{Fe}_{2} \mathrm{O}_{3} / \mathrm{Al}_{2} \mathrm{O}_{3} / \mathrm{TiO}_{2}$ oxygen carriers. Similar results were also observed for $\mathrm{Fe}_{2} \mathrm{O}_{3} / \mathrm{Al}_{2} \mathrm{O}_{3}$ and $\mathrm{Fe}_{2} \mathrm{O}_{3} / \mathrm{Al}_{2} \mathrm{O}_{3} / \mathrm{TiO}_{2}$ reduction conducted with same operating temperature, as shown in Fig. 3, because the activation energies for the product layer diffusion reaction $\left(E a_{p l}\right)$ were respectively determined to be $255.35 \mathrm{~kJ} \mathrm{~mol}^{-1}$ and $265.91 \mathrm{~kJ} \mathrm{~mol}^{-1}$ for $\mathrm{Fe}_{2} \mathrm{O}_{3} / \mathrm{Al}_{2} \mathrm{O}_{3}$ and $\mathrm{Fe}_{2} \mathrm{O}_{3} / \mathrm{Al}_{2} \mathrm{O}_{3} / \mathrm{TiO}_{2}$ reduction with $\mathrm{CO}$. For experiments conducted at operating temperature ranged from 875 to $925^{\circ} \mathrm{C}$, the decay constants $\left(k_{d}\right)$ of $\mathrm{Fe}_{2} \mathrm{O}_{3} / \mathrm{Al}_{2} \mathrm{O}_{3}$ and $\mathrm{Fe}_{2} \mathrm{O}_{3} / \mathrm{Al}_{2} \mathrm{O}_{3} / \mathrm{TiO}_{2}$ were determined to be in the range of 7.8 to 10.1 and 12.7 to 14.2 , respectively. Higher $k_{d}$ was obtained for experiments with $\mathrm{Fe}_{2} \mathrm{O}_{3} / \mathrm{Al}_{2} \mathrm{O}_{3} / \mathrm{TiO}_{2}$ particles than those with $\mathrm{Fe}_{2} \mathrm{O}_{3} / \mathrm{Al}_{2} \mathrm{O}_{3}$ particles, demonstrating that the $D_{e}$ of $\mathrm{Fe}_{2} \mathrm{O}_{3} / \mathrm{Al}_{2} \mathrm{O}_{3} / \mathrm{TiO}_{2}$ oxygen carriers was more easily depended on the oxygen carrier conversion. Hence, for experiments conducted with the conversion of $\mathrm{Fe}_{2} \mathrm{O}_{3} / \mathrm{Al}_{2} \mathrm{O}_{3} / \mathrm{TiO}_{2}$ oxygen carrier higher than $33.33 \%$, the slope of the reduction conversion vs. time curves was found to be significantly decreased. Furthermore, the slope of the reduction conversion vs. time curves was observed to be slightly altered for experiments conducted at various operating temperature, which might be also attributed to the decay constant $\left(k_{d}\right)$ was dependent on the operating temperatures, consistent with the result found in literature (de Diego et al., 2014; Abad et al., 2015). For experiments conducted with an operating temperature of $900^{\circ} \mathrm{C}$, the slope of the $\mathrm{Fe}_{2} \mathrm{O}_{3} / \mathrm{Al}_{2} \mathrm{O}_{3}$ reduction conversion vs. time curves were changed with inlet $\mathrm{CO}$ concentration ranged from 5 to $20 \%$, as shown in Fig. 4 , possibly due to high $k_{d, 0}$ was obtained for $\mathrm{Fe}_{2} \mathrm{O}_{3} / \mathrm{Al}_{2} \mathrm{O}_{3}$ reduction with $\mathrm{CO}$ (Cabello et al., 2014).

\section{Charcoal Gasification with Steam in an Empty Bed Reactor}

Steam was employed to be a gasification agent, and the main mechanism of the charcoal gasification in the steamcontaining gaseous stream could be described as the following (Gayán et al., 2010; Cuadrat et al., 2011; Wu et al., 2015):

Charcoal $\rightarrow$ Volatile matter + Char

$$
C_{n} H_{m}+n H_{2} \mathrm{O} \leftrightarrow\left(n+\frac{m}{2}\right) H_{2}+n C O
$$

\begin{tabular}{|c|c|c|c|c|}
\hline Parameter & Symbol & Unit & $\mathrm{Fe}_{2} \mathrm{O}_{3} / \mathrm{Al}_{2} \mathrm{O}_{3}$ & $\mathrm{Fe}_{2} \mathrm{O}_{3} / \mathrm{Al}_{2} \mathrm{O}_{3} / \mathrm{TiO}_{2}$ \\
\hline Mass transfer coefficient & $k_{g}$ & $\mathrm{~mm} \mathrm{~s}^{-1}$ & 0.16 & 0.22 \\
\hline Pre-exponential factor for the product layer diffusion reaction & $D_{p l, 0}$ & $\mathrm{~mm}^{2} \mathrm{~s}^{-1}$ & $1.34 \times 10^{11}$ & $9.09 \times 10^{11}$ \\
\hline Activation energy for the product layer diffusion reaction & $E_{p l}$ & $\mathrm{~kJ} \mathrm{~mol}^{-1}$ & 255.35 & 265.91 \\
\hline Pre-exponential factor for the product layer diffusivity & $k_{d, 0}$ & - & 3737.23 & 162.86 \\
\hline Activation energy for the product layer diffusivity & $E_{d}$ & $\mathrm{~kJ} \mathrm{~mol}^{-1}$ & 58.91 & 24.34 \\
\hline
\end{tabular}

$\mathrm{CO}+\mathrm{H}_{2} \mathrm{O} \rightarrow \mathrm{CO}_{2}+\mathrm{H}_{2}$

$\mathrm{Char}+\mathrm{H}_{2} \mathrm{O} \rightarrow \mathrm{CO}+\mathrm{H}_{2}+\mathrm{Ash}$

Table 3. Kinetics parameters for the reduction of iron-based oxygen carriers conducted with CO. 
The concentrations of the gaseous products for the gasification of charcoal by steam at various operating temperature are shown in Fig. 5. Elevated operating temperature increased the $\mathrm{CO}$ concentration, whereas diminished the $\mathrm{CO}_{2}$ and $\mathrm{CH}_{4}$ concentrations. It is ascribed that the endothermic reactions (steam reforming reaction and char gasification) are favorably occurred at higher operating temperature, instead the exothermic reaction (water gas shift reaction) is not favorable (Chiu et al., 2014b). In addition, the $\mathrm{H}_{2}$ concentration was slightly declined with the operating temperature between $850^{\circ} \mathrm{C}$ and $900^{\circ} \mathrm{C}$, due to the less volatile matter contained in charcoal. Fig. 6 shows the gaseous product concentrations during charcoal gasification at various steam flow rate.

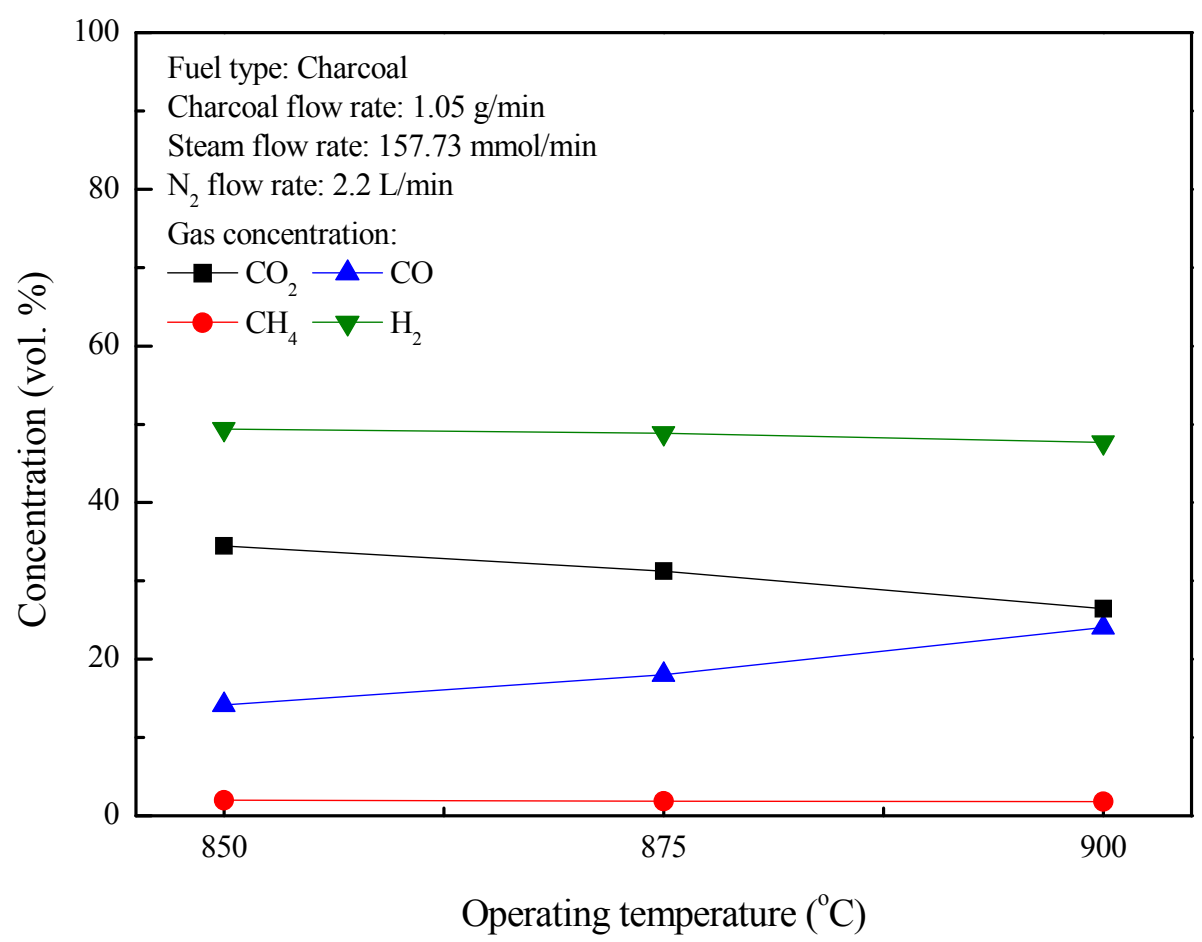

Fig. 5. Effect of operating temperature on the gasification of charcoal in the empty bed.

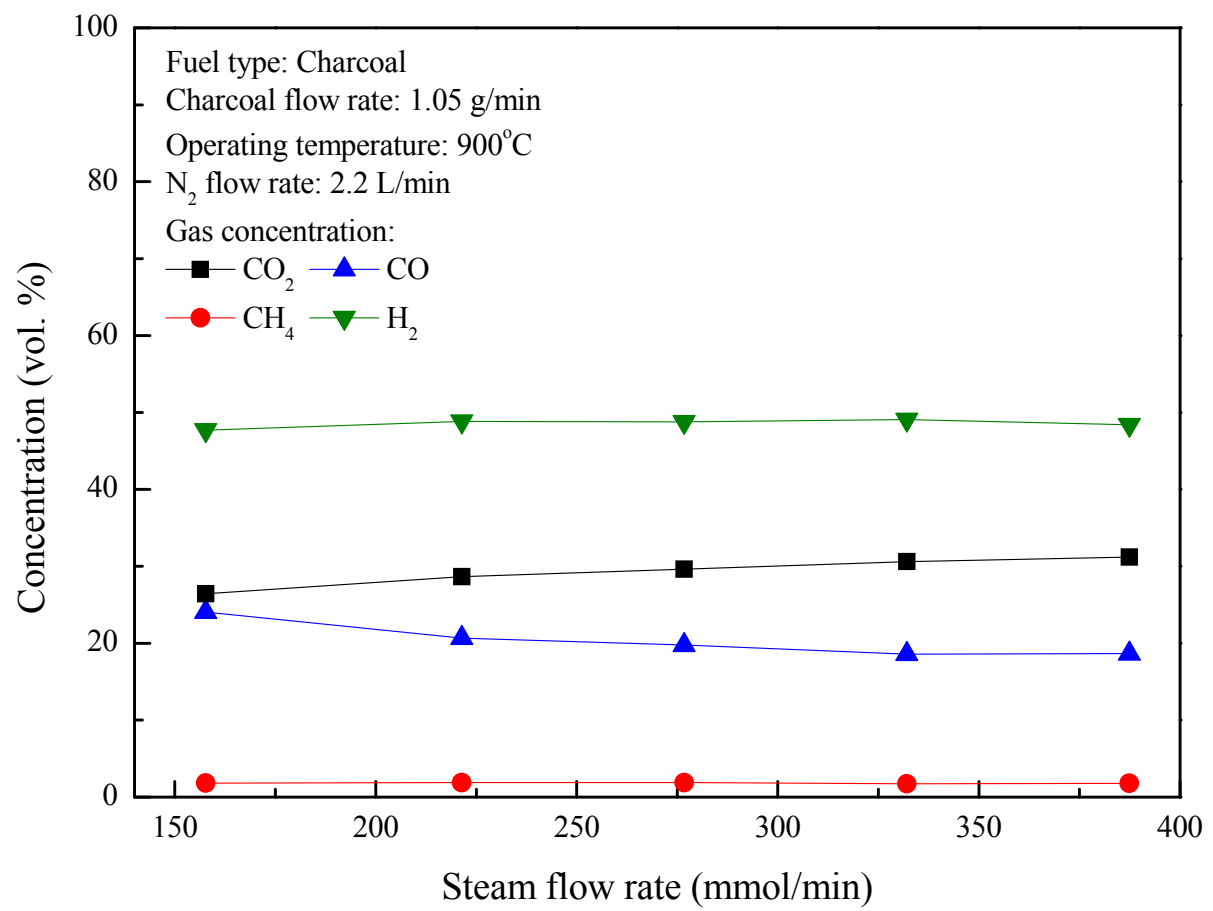

Fig. 6. Effect of steam flow rate on the gasification of charcoal in the empty bed. 
Increased steam flow rate diminished the $\mathrm{CO}$ and $\mathrm{CH}_{4}$ concentrations, whereas enhanced the $\mathrm{CO}_{2}$ and $\mathrm{H}_{2}$ concentrations. Experiments conducted with high steam flow rate might be beneficial for steam reforming reaction and water gas shift reaction.

\section{CLC of Charcoal by $\mathrm{Fe}_{2} \mathrm{O}_{3} / \mathrm{Al}_{2} \mathrm{O}_{3}$ Particles}

A series of experiments were carried out to study the CLC of charcoal by $\mathrm{Fe}_{2} \mathrm{O}_{3} / \mathrm{Al}_{2} \mathrm{O}_{3}$ particles. Results for experiments conducted at different steam flowrates are presented in Fig. 7. The maximum concentration of $\mathrm{CO}_{2}$ was obtained at inlet steam flowrate of $157.7 \mathrm{mmol} \mathrm{min}^{-1}$. The result implied that the combustible gaseous products $\left(\mathrm{H}_{2}, \mathrm{CO}\right.$, and $\left.\mathrm{CH}_{4}\right)$ generated from charcoal gasification were completely combusted by the oxygen carrier. However, the $\mathrm{CO}_{2}$ concentration was significantly dwindled by increasing the steam flowrate. The enhancement of $\mathrm{H}_{2}$ and $\mathrm{CO}$ concentrations could be attributed to the incomplete combustion of fuel gas generated from charcoal gasification. The carbon conversion $\left(X_{C}\right)$ and the oxygen carrier conversion $\left(X_{O C}\right)$ for charcoal combustion were determined using the following relationship:

$$
\begin{aligned}
X_{C}= & \frac{F_{\mathrm{CO}_{2}}+F_{\mathrm{CO}}+F_{\mathrm{CH}_{4}}}{F_{C, \text { in }}} \\
X_{\mathrm{OC}} & =\frac{\left(2 F_{\mathrm{CO}_{2}}+F_{C O}+F_{\mathrm{H}_{2} \mathrm{O}}+F_{O, \text { out }}\right)-\left(F_{O, \text { in }}+F_{\mathrm{H}_{2} \mathrm{O}, \text { in }}\right)}{\left(\frac{x_{\mathrm{Fe}_{2} \mathrm{O}_{3}} \cdot \dot{m}_{\mathrm{OC}}}{M_{\mathrm{Fe}_{2} \mathrm{O}_{3}}}\right) \times 1000 \times 3}
\end{aligned}
$$

$$
\begin{aligned}
& \dot{m}_{\text {Charcoal }, \text { out }}=\dot{m}_{\text {Charcoal }, \text { in }}\left(1-X_{C}\right) \\
& F_{H_{2} \mathrm{O}}=\left(0.5 F_{H, \text { in }}+F_{H_{2} \text {, in }}\right)-\left(0.5 F_{H, \text { out }}+F_{H_{2}}+F_{C H_{4}}\right) \\
& F_{H, \text { out }}=\frac{2.11 \% \times \dot{m}_{\text {Charcoal }, \text { out }}}{M_{H}} \times 1000 \\
& F_{O, \text { out }}=\frac{2.69 \% \times \dot{m}_{\text {Charcoal }, \text { out }}}{M_{O}} \times 1000
\end{aligned}
$$

where $F_{i}$ is the effluent molar flowrate $\left(\mathrm{mmol} \mathrm{min}{ }^{-1}\right)$ of species $i ; i$ is denoted as $\mathrm{CO}_{2}, \mathrm{CO}, \mathrm{H}_{2} \mathrm{O}, \mathrm{H}_{2}$ and $\mathrm{CH}_{4} ; F_{C, i n}$, $F_{H, \text { in }}$ and $F_{O, \text { in }}$ are the inlet carbon, hydrogen and oxygen mole flow rate $\left(\mathrm{mmol} \mathrm{min}^{-1}\right)$ of charcoal, respectively; $F_{O \text { out }}$ and $F_{H, o u t}$ are the outlet oxygen and hydrogen mole flow rate $\left(\mathrm{mmol} \mathrm{min}^{-1}\right)$ of unburned charcoal, respectively; $F_{\mathrm{H}_{2} \mathrm{O} \text {, in }}$ is the inlet mole flow rate $\left(\mathrm{mmol} \mathrm{min}^{-1}\right)$ of $\mathrm{H}_{2} \mathrm{O}$; $\dot{m}_{\text {Charcoal, in }}$ and $\dot{m}_{\text {Charcoal,out }}$ are the inlet and outlet mass flow rate $\left(\mathrm{g} \mathrm{min}^{-1}\right)$ of charcoal; $\dot{m}_{O C}$ is the mass flow rate $\left(\mathrm{g} \mathrm{min}^{-1}\right)$ of the oxygen carriers in the ADMBR. Fig. 8 shows the effect of inlet steam flow rate on the combustion of charcoal by the CLC process with $\mathrm{Fe}_{2} \mathrm{O}_{3} / \mathrm{Al}_{2} \mathrm{O}_{3}$ oxygen carriers in the ADMBR operated at $900^{\circ} \mathrm{C}$. For steam feeding rate

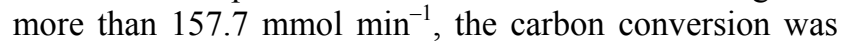
retained to about $60 \%$, indicating that charcoal gasification was not significantly enhanced with the application of more steam, due to charcoal gasification is the limiting step, consistent with the data found in the literature (Luo et al., 2014b). Hence, the longer residence time is required

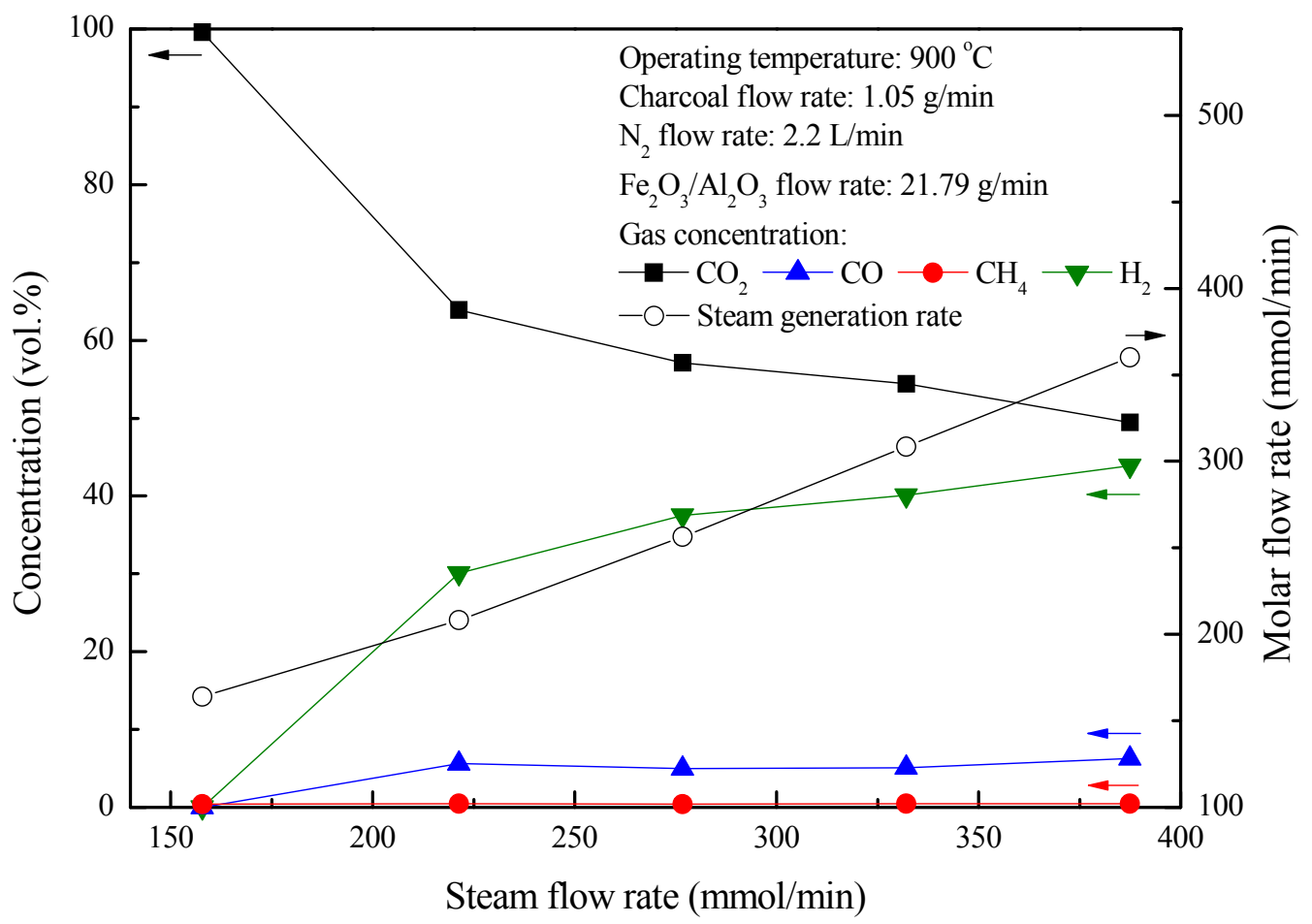

Fig. 7. Effect of steam flow rates on the combustion of charcoal with $\mathrm{Fe}_{2} \mathrm{O}_{3} / \mathrm{Al}_{2} \mathrm{O}_{3}$ in the moving bed. 


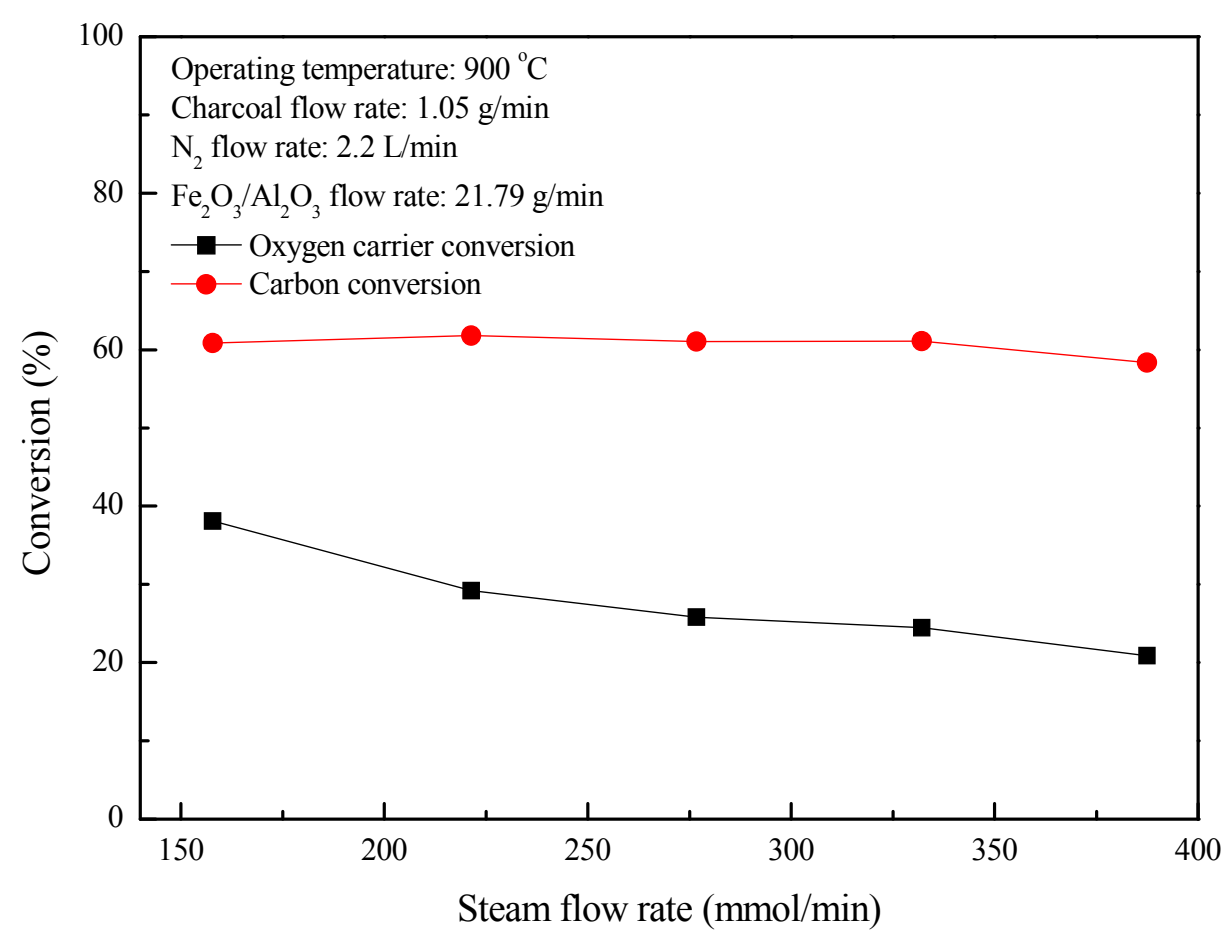

Fig. 8. Effect of steam flow rates on fuel and oxygen carrier conversions for CLC of charcoal with $\mathrm{Fe}_{2} \mathrm{O}_{3} / \mathrm{Al}_{2} \mathrm{O}_{3}$ in the moving bed.

for the gasification of charcoal occurred in the fuel reactor. Experimental results illustrated in Fig. 8 also exhibited that the almost complete reaction between $\mathrm{Fe}_{2} \mathrm{O}_{3} / \mathrm{Al}_{2} \mathrm{O}_{3}$ oxygen carriers and fuel gases generated from the charcoal gasification could be accomplished for the experiment conducted with inlet steam flow rate of $157.7 \mathrm{mmol} \mathrm{min}^{-1}$. However, as for experiments conducted with carbon conversion of about $60 \%$, the effluent concentrations of $\mathrm{H}_{2}$ and $\mathrm{CO}$ were enhanced with steam feeding rate ranged

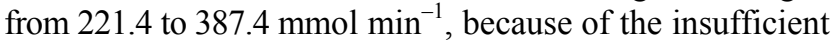
residence time was provided for the CLC of fuel gases with $\mathrm{Fe}_{2} \mathrm{O}_{3} / \mathrm{Al}_{2} \mathrm{O}_{3}$ particles. As also indicated in Fig. 8, the maximum conversion of $\mathrm{Fe}_{2} \mathrm{O}_{3} / \mathrm{Al}_{2} \mathrm{O}_{3}$ particles (nearly $38 \%$ ) was obtained for the combustion of charcoal with

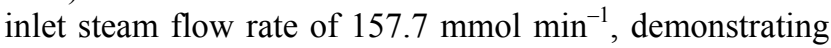
the component of reduced oxygen carriers was majorly $\mathrm{FeO}$, consistent with the result found in the literature (Luo et al., 2014b). Nevertheless, the oxygen carrier conversions of $\mathrm{Fe}_{2} \mathrm{O}_{3} / \mathrm{Al}_{2} \mathrm{O}_{3}$ particles were found to decrease with increasing inlet steam flowrate, because less $\mathrm{Fe}_{2} \mathrm{O}_{3} / \mathrm{Al}_{2} \mathrm{O}_{3}$ oxygen carriers were considered to be reduced by fuel gases, such as $\mathrm{CH}_{4}, \mathrm{CO}$, and $\mathrm{H}_{2}$, which is generated by char gasification and combustion.

\section{CLC of Charcoal by $\mathrm{Fe}_{2} \mathrm{O}_{3} / \mathrm{Al}_{2} \mathrm{O}_{3} / \mathrm{TiO}_{2}$ Particles}

CLC experiments were conducted in this study to examine the combustion of charcoal under various inlet steam flow rate. As the experimental results illustrated in Fig. 9, outlet gas stream containing about $99 \% \mathrm{CO}_{2}$ and $1 \% \mathrm{CH}_{4}$ were achieved for experiments with inlet steam flowrate operated between $157.7 \mathrm{mmol} \mathrm{min}^{-1}$ and $221.4 \mathrm{mmol} \mathrm{min}^{-1}$, but the effluent concentration of $\mathrm{CO}_{2}$ was dropped for experiments carried out with inlet steam flow rate of $276.7 \mathrm{mmol} \mathrm{min}^{-1}$. These experimental observations may be attributed due to more combustible gas $\left(\mathrm{CH}_{4}, \mathrm{H}_{2}\right.$, and $\left.\mathrm{CO}\right)$ generated by Eqs. (13)-(16) were higher than that consumed by $\mathrm{Fe}_{2} \mathrm{O}_{3} / \mathrm{Al}_{2} \mathrm{O}_{3} / \mathrm{TiO}_{2}$ reduction reaction. Further increases of

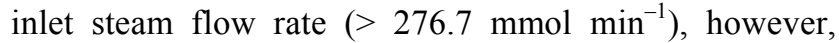
could enhance the $\mathrm{CO}_{2}$ and $\mathrm{CH}_{4}$ effluent concentrations, and decrease the $\mathrm{H}_{2}$ and $\mathrm{CO}$ effluent concentrations. The only slightly enhanced methane concentration may be ascribed to the low reactivity of the iron-based oxygen carriers with methane. The injections of excessive steam inhibited charcoal gasification due to insufficient residence time was provided. Thus, less charcoal was gasified to generate methane, hydrogen and carbon monoxide, and then hydrogen and carbon monoxide were further combusted with $\mathrm{Fe}_{2} \mathrm{O}_{3} / \mathrm{Al}_{2} \mathrm{O}_{3} / \mathrm{TiO}_{2}$ oxygen carrier to generate carbon dioxide and steam. Besides, fewer $\mathrm{H}_{2}$ and $\mathrm{CO}$ outlet concentration were observed for charcoal combustion with $\mathrm{Fe}_{2} \mathrm{O}_{3} / \mathrm{Al}_{2} \mathrm{O}_{3} / \mathrm{TiO}_{2}$ particle than those with $\mathrm{Fe}_{2} \mathrm{O}_{3} / \mathrm{Al}_{2} \mathrm{O}_{3}$ particle, because of the hydrogen and carbon monoxide were considered to be consumed more rapidly by $\mathrm{Fe}_{2} \mathrm{O}_{3} / \mathrm{Al}_{2} \mathrm{O}_{3} / \mathrm{TiO}_{2}$ reduction reaction than by $\mathrm{Fe}_{2} \mathrm{O}_{3} / \mathrm{Al}_{2} \mathrm{O}_{3}$ reduction reaction. Fig. 10 shows that carbon conversions were obviously increased for charcoal combustion conducted with $7.5 \mathrm{~g} \mathrm{~min}^{-1} \mathrm{Fe}_{2} \mathrm{O}_{3} / \mathrm{Al}_{2} \mathrm{O}_{3} / \mathrm{TiO}_{2}$ particles, and inlet steam flow rate ranged from 157.7 to

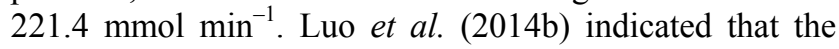
kinetic of charcoal gasification was enhanced by increasing the flow rate of the gasification agent. More $\mathrm{H}_{2} \mathrm{O}$ and $\mathrm{CO}_{2}$ were produced from fuel gases combustion and was subsequently reacted with charcoal to perform gasification reaction, consistent with the results found in the literatures 


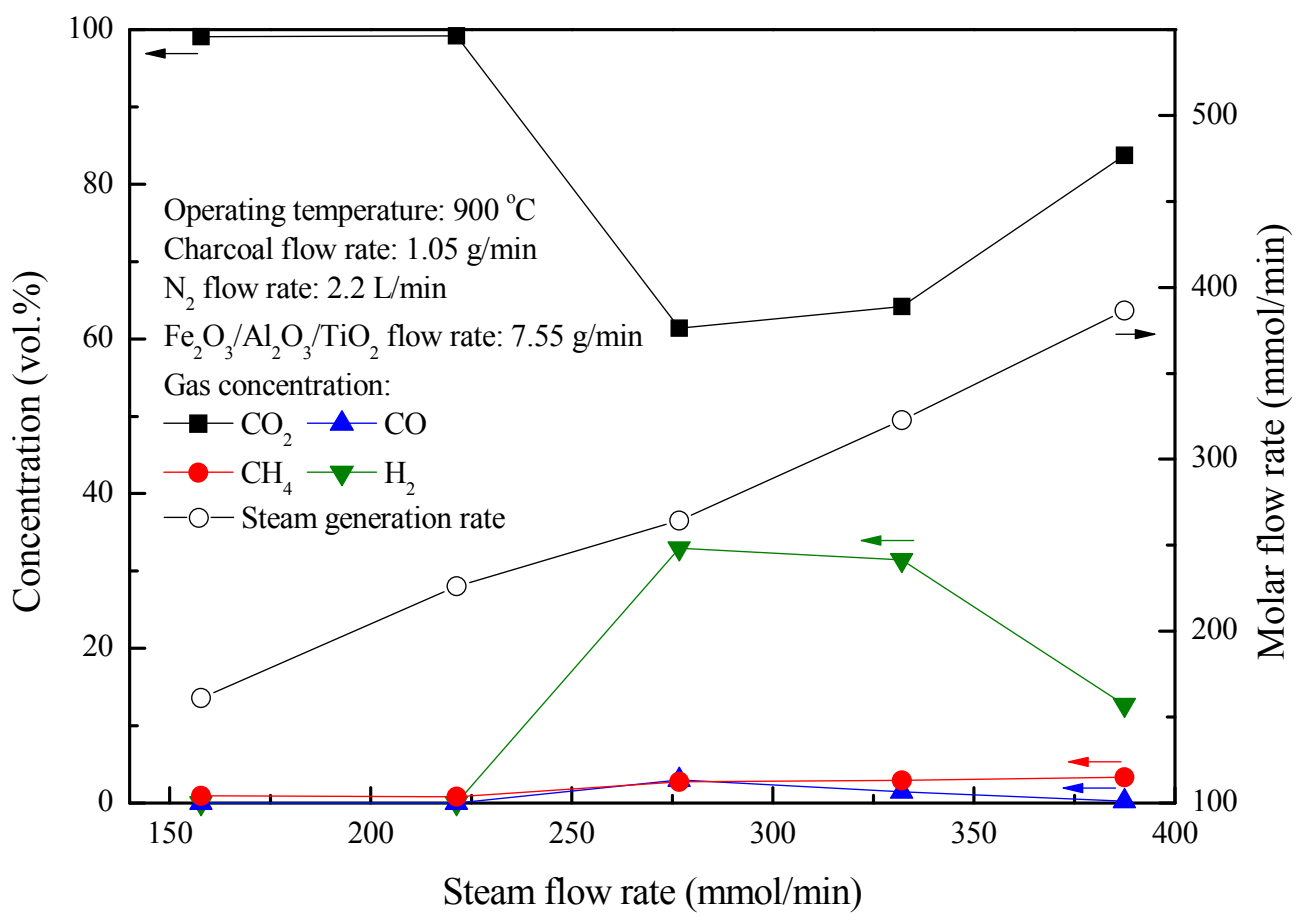

Fig. 9. Effect of steam flow rates on the combustion of charcoal with $\mathrm{Fe}_{2} \mathrm{O}_{3} / \mathrm{Al}_{2} \mathrm{O}_{3} / \mathrm{TiO}_{2}$ in the moving bed.

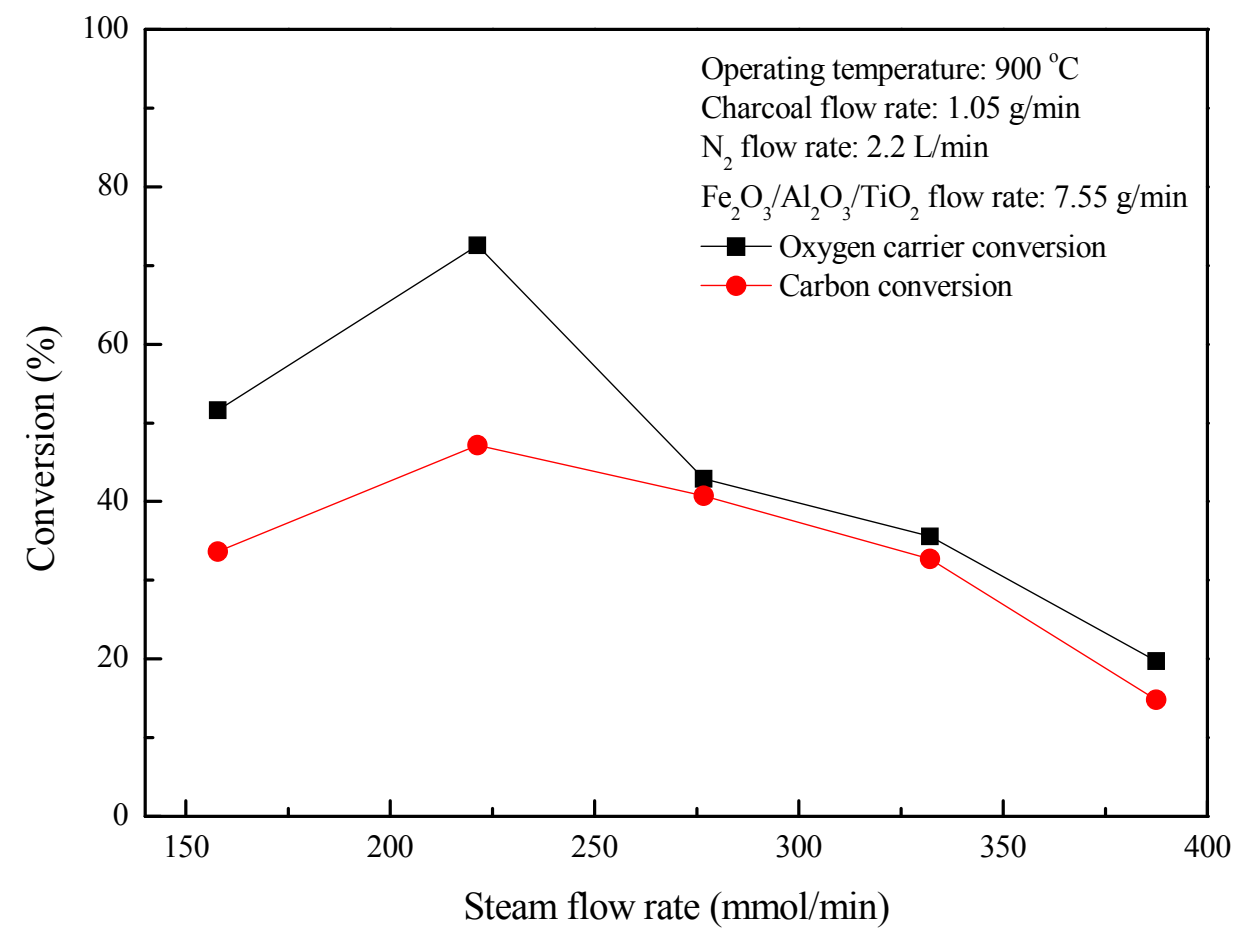

Fig. 10. Effect of steam flow rates on fuel and oxygen carrier conversions for CLC of charcoal with $\mathrm{Fe}_{2} \mathrm{O}_{3} / \mathrm{Al}_{2} \mathrm{O}_{3} / \mathrm{TiO}_{2}$ in the moving bed.

(Fan, 2010; $\mathrm{Wu}$ and $\mathrm{Ku}, 2016$ ). However, the carbon conversions were found to be diminished by the addition of excessive steam $\left(>221.4 \mathrm{mmol} \mathrm{min}{ }^{-1}\right)$. The carbon conversions were decreased for CLC of charcoal is possibly caused by the fuel gases not immediately combusted with $\mathrm{Fe}_{2} \mathrm{O}_{3} / \mathrm{Al}_{2} \mathrm{O}_{3} / \mathrm{TiO}_{2}$ oxygen carriers, and more $\mathrm{H}_{2}$ and $\mathrm{CO}$ were presented in the fuel reactor effluent. As shown in Figs. 8 and 10, maximum carbon conversion of around $61.8 \%$ was achieved for charcoal combustion with $\mathrm{Fe}_{2} \mathrm{O}_{3} / \mathrm{Al}_{2} \mathrm{O}_{3}$, while the maximum carbon conversion of charcoal combustion with $\mathrm{Fe}_{2} \mathrm{O}_{3} / \mathrm{Al}_{2} \mathrm{O}_{3} / \mathrm{TiO}_{2}$ reached about $47.2 \%$ for experiments conducted with inlet steam flow rate of 


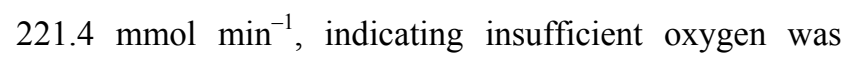
provided to fully combust charcoal. Fewer carbon conversions were observed for the combustion of charcoal with $\mathrm{Fe}_{2} \mathrm{O}_{3} / \mathrm{Al}_{2} \mathrm{O}_{3} / \mathrm{TiO}_{2}$ than that for charcoal combustion with $\mathrm{Fe}_{2} \mathrm{O}_{3} / \mathrm{Al}_{2} \mathrm{O}_{3}$, further demonstrating charcoal gasification was impeded because the amount of $\mathrm{Fe}_{2} \mathrm{O}_{3} / \mathrm{Al}_{2} \mathrm{O}_{3} / \mathrm{TiO}_{2}$ mass flow for charcoal combustion was lower than that of $\mathrm{Fe}_{2} \mathrm{O}_{3} / \mathrm{Al}_{2} \mathrm{O}_{3}$ mass flow.

Fig. 10 reveals the $X_{O C}$ of $\mathrm{Fe}_{2} \mathrm{O}_{3} / \mathrm{Al}_{2} \mathrm{O}_{3} / \mathrm{TiO}_{2}$ particles were enhanced for experiments conducted with inlet steam flow rate ranged from 157.7 to $221.4 \mathrm{mmol} \mathrm{min}^{-1}$, demonstrating increased steam flow rate to promote the charcoal gasification, and further enhance the $\mathrm{Fe}_{2} \mathrm{O}_{3} / \mathrm{Al}_{2} \mathrm{O}_{3} / \mathrm{TiO}_{2}$ reduction. Subsequently, the oxygen carrier conversion was markedly dropped with inlet steam flow rate ranged from 221.4 to $387.4 \mathrm{mmol} \mathrm{min}^{-1}$, indicating not enough residence time was provided to reduce $\mathrm{Fe}_{2} \mathrm{O}_{3} / \mathrm{Al}_{2} \mathrm{O}_{3} / \mathrm{TiO}_{2}$ oxygen carriers with the fuel gases generated by char gasification and combustion. Thus, experiments conducted with excessive inlet steam flow rate might not be favorable to perform ironbased oxygen carrier reduction. Less oxygen carrier was demanded for the combustion of charcoal with $\mathrm{Fe}_{2} \mathrm{O}_{3} / \mathrm{Al}_{2} \mathrm{O}_{3} / \mathrm{TiO}_{2}$ than that for charcoal combustion with $\mathrm{Fe}_{2} \mathrm{O}_{3} / \mathrm{Al}_{2} \mathrm{O}_{3}$, probably because lattice oxygen present in the $\mathrm{Fe}_{2} \mathrm{O}_{3} / \mathrm{Al}_{2} \mathrm{O}_{3} / \mathrm{TiO}_{2}$ oxygen carriers are more ready to react with combustible gas, especially hydrogen and carbon monoxide. Moreover, fewer oxygen carriers are required may also be ascribed to the higher $\mathrm{Fe}_{2} \mathrm{O}_{3}$ contained in the $\mathrm{Fe}_{2} \mathrm{O}_{3} / \mathrm{Al}_{2} \mathrm{O}_{3} / \mathrm{TiO}_{2}$ oxygen carrier. Abad et al. (2007) analyzed the design criteria for a CLC system and reported that the solid circulation rate was decreased with increasing the metal oxide content for the combustion of fuel gases $\left(\mathrm{H}_{2}, \mathrm{CO}\right.$, and $\left.\mathrm{CH}_{4}\right)$ with different metal oxides $(\mathrm{CuO}, \mathrm{NiO}$, and $\mathrm{Fe}_{2} \mathrm{O}_{3}$ ).

\section{Crystalline Phase Identification and Heat Analysis}

The XRD diffraction peaks of prepared $\mathrm{Fe}_{2} \mathrm{O}_{3} / \mathrm{Al}_{2} \mathrm{O}_{3}$ particles for the crystal-phase transformation are presented in Fig. 11, indicating that only $\mathrm{Fe}_{2} \mathrm{O}_{3}$ and $\mathrm{Al}_{2} \mathrm{O}_{3}$ are found for fresh oxygen carriers. However, the crystal phases of the reduced $\mathrm{Fe}_{2} \mathrm{O}_{3} / \mathrm{Al}_{2} \mathrm{O}_{3}$ particles identified from the XRD spectra can be classified into three components of $\mathrm{Al}_{2} \mathrm{FeO}_{4}, \mathrm{Fe}_{3} \mathrm{O}_{4}$, and $\mathrm{Al}_{2} \mathrm{O}_{3}$, indicating that the amount of oxygen utilization from $\mathrm{F}_{2} \mathrm{O}_{3}$ to slightly $\mathrm{Fe}_{3} \mathrm{O}_{4}$ and $\mathrm{FeO}$. A similar observation was obtained by Ishida et al. (2005) and $\mathrm{Ku}$ et al. (2014). Zhu et al. (2016) analyzed the atomic structural evolution during the reduction of $\alpha-\mathrm{Fe}_{2} \mathrm{O}_{3}$ nanowires and also reported that more oxygen vacancies were formed as the reduction continues. Thus, the rhombohedral structure of $\alpha-\mathrm{Fe}_{2} \mathrm{O}_{3}$ become unstable and transformed into the cubic structure of $\mathrm{Fe}_{3} \mathrm{O}_{4}$. In this study, $\mathrm{Fe}_{3} \mathrm{O}_{4}$ was further reduced to form the cubic structure of $\mathrm{Al}_{2} \mathrm{FeO}_{4}$. Few $\mathrm{Fe}_{3} \mathrm{O}_{4}$ was observed in the reduced $\mathrm{Fe}_{2} \mathrm{O}_{3} / \mathrm{Al}_{2} \mathrm{O}_{3}$ particles possibly due to the presence of insufficient residence time. Subsequently, the reduced $\mathrm{Fe}_{2} \mathrm{O}_{3} / \mathrm{Al}_{2} \mathrm{O}_{3}$ oxygen carriers were completely oxidized by air to generate $\mathrm{Fe}_{2} \mathrm{O}_{3}$ and $\mathrm{Al}_{2} \mathrm{O}_{3}$, which were observed in the XRD pattern.

As shown in Fig. 12, $\mathrm{Fe}_{2} \mathrm{O}_{3}, \mathrm{Fe}_{2} \mathrm{TiO}_{5}$ and $\mathrm{Al}_{2} \mathrm{O}_{3}$ were the major crystalline phases of fresh $\mathrm{Fe}_{2} \mathrm{O}_{3} / \mathrm{Al}_{2} \mathrm{O}_{3} / \mathrm{TiO}_{2}$ oxygen carriers. For an experiment conducted with inlet steam flow rate of $387.4 \mathrm{mmol} \mathrm{min}^{-1}$ and $\mathrm{Fe}_{2} \mathrm{O}_{3} / \mathrm{Al}_{2} \mathrm{O}_{3} / \mathrm{TiO}_{2}$ flow

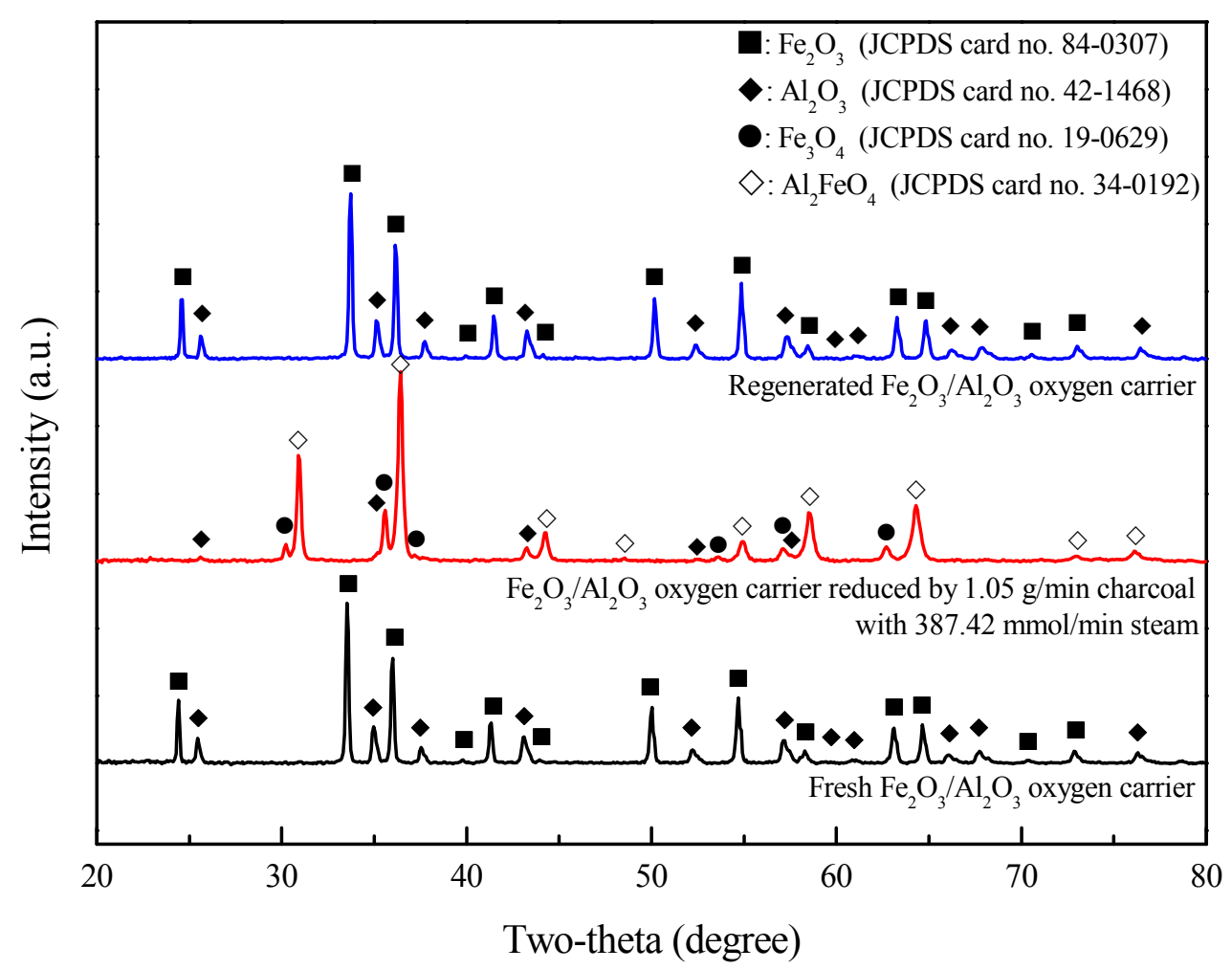

Fig. 11. X-ray diffraction patterns of fresh, reduced and regenerated $\mathrm{Fe}_{2} \mathrm{O}_{3} / \mathrm{Al}_{2} \mathrm{O}_{3}$ oxygen carriers for charcoal combustion. 


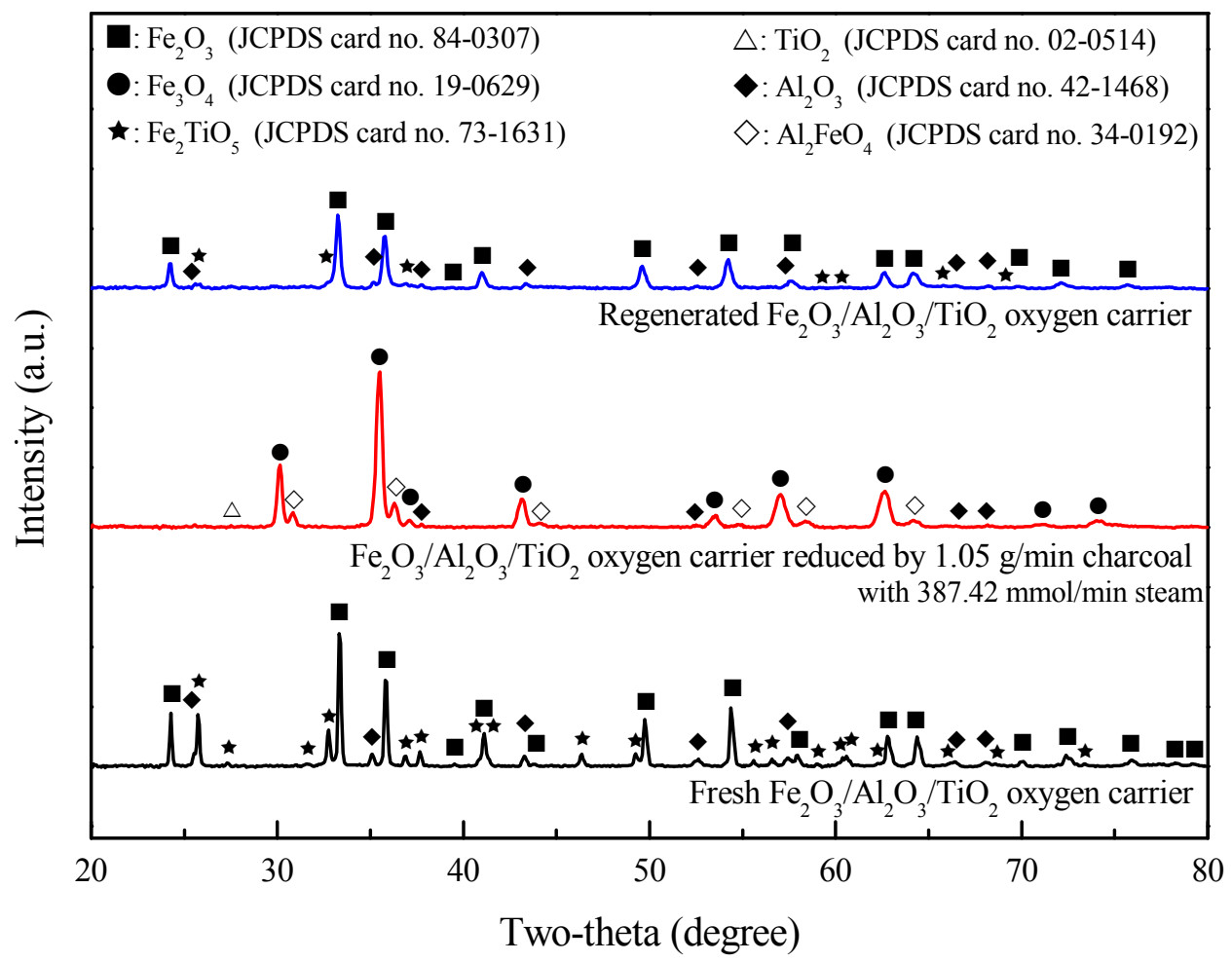

Fig. 12. X-ray diffraction patterns of fresh, reduced and regenerated $\mathrm{Fe}_{2} \mathrm{O}_{3} / \mathrm{Al}_{2} \mathrm{O}_{3} / \mathrm{TiO}_{2}$ oxygen carriers for charcoal combustion.

rate of $7.55 \mathrm{~g} \mathrm{~min}^{-1}$, the reduced $\mathrm{Fe}_{2} \mathrm{O}_{3} / \mathrm{Al}_{2} \mathrm{O}_{3} / \mathrm{TiO}_{2}$ oxygen carriers were sampled from moving bed operation. The absence of $\mathrm{Fe}_{2} \mathrm{O}_{3}$ and $\mathrm{Fe}_{2} \mathrm{TiO}_{5}$ in the XRD pattern indicated that $\mathrm{Fe}_{2} \mathrm{O}_{3}$ and $\mathrm{Fe}_{2} \mathrm{TiO}_{5}$ were completely reduced. Hence, the rhombohedral structure of $\alpha-\mathrm{Fe}_{2} \mathrm{O}_{3}$ and the orthorhombic structure of $\mathrm{Fe}_{2} \mathrm{TiO}_{5}$ were transformed into the cubic structure of $\mathrm{Fe}_{3} \mathrm{O}_{4}$ and $\mathrm{Al}_{2} \mathrm{FeO}_{4}$, as illustrated in Fig. 12 . Similar results were obtained in the investigation of $\mathrm{Abad}$ et al. (2011) and $\mathrm{Zhu}$ et al. (2016). For $\mathrm{Fe}_{2} \mathrm{O}_{3} / \mathrm{Al}_{2} \mathrm{O}_{3} / \mathrm{TiO}_{2}$ oxygen carriers sampled after regeneration, $\mathrm{Fe}_{2} \mathrm{O}_{3}, \mathrm{Fe}_{2} \mathrm{TiO}_{5}$, and $\mathrm{Al}_{2} \mathrm{O}_{3}$ were observed in the XRD pattern, demonstrating that $\mathrm{Fe}_{3} \mathrm{O}_{4}, \mathrm{Al}_{2} \mathrm{FeO}_{4}, \mathrm{Al}_{2} \mathrm{O}_{3}$ and slightly $\mathrm{TiO}_{2}$ contained in the reduced $\mathrm{Fe}_{2} \mathrm{O}_{3} / \mathrm{Al}_{2} \mathrm{O}_{3} / \mathrm{TiO}_{2}$ oxygen carriers were completely oxidized to $\mathrm{Fe}_{2} \mathrm{O}_{3}, \mathrm{Fe}_{2} \mathrm{TiO}_{5}$, and $\mathrm{Al}_{2} \mathrm{O}_{3}$.

The mechanism for reduction of $\mathrm{Fe}_{2} \mathrm{O}_{3} / \mathrm{Al}_{2} \mathrm{O}_{3}$ and $\mathrm{Fe}_{2} \mathrm{O}_{3} / \mathrm{Al}_{2} \mathrm{O}_{3} / \mathrm{TiO}_{2}$ oxygen carriers with $\mathrm{CO}$ or $\mathrm{H}_{2}$ are proposed as Eqs. (23)-(26) based on the experimental results of this study. Unfortunately, the oxygen carrier conversion contributed by each reduction reactions were not possible to be separated because these reduction reactions may occur simultaneously. Therefore, the overall reduction reaction of iron-based oxygen carrier for methane combustion is summarized and simplified by Integrated Rate of Reduction (IRoR) model, which has been widely used for evaluating the total reduction rate of iron ores (Abad et al., 2011).

For $\mathrm{Fe}_{2} \mathrm{O}_{3} / \mathrm{Al}_{2} \mathrm{O}_{3}$ reduction:

$$
\begin{aligned}
& \mathrm{Fe}_{2} \mathrm{O}_{3}+2 \mathrm{Al}_{2} \mathrm{O}_{3}+\mathrm{CO} / \mathrm{H}_{2} \leftrightarrow 2 \mathrm{Al}_{2} \mathrm{FeO}_{4}+\mathrm{CO}_{2} / \mathrm{H}_{2} \mathrm{O} \\
& 3 \mathrm{Fe}_{2} \mathrm{O}_{3}+\mathrm{CO} / \mathrm{H}_{2} \leftrightarrow 2 \mathrm{Fe}_{3} \mathrm{O}_{4}+\mathrm{CO}_{2} / \mathrm{H}_{2} \mathrm{O}
\end{aligned}
$$

For $\mathrm{Fe}_{2} \mathrm{O}_{3} / \mathrm{Al}_{2} \mathrm{O}_{3} / \mathrm{TiO}_{2}$ reduction:

$$
\begin{aligned}
& \mathrm{Fe}_{2} \mathrm{TiO}_{5}+\mathrm{TiO}_{2}+\mathrm{CO} / \mathrm{H}_{2} \leftrightarrow 2 \mathrm{Fe}_{2} \mathrm{TiO}_{3}+\mathrm{CO}_{2} / \mathrm{H}_{2} \mathrm{O} \\
& \mathrm{FeTiO}_{3}+\mathrm{CO} / \mathrm{H}_{2} \leftrightarrow \mathrm{Fe}+\mathrm{TiO}_{2}+\mathrm{CO}_{2} / \mathrm{H}_{2} \mathrm{O}
\end{aligned}
$$

The definition of input processing capacity $\left(Q_{i n}\right)$ and output processing capacity for charcoal combustion $\left(Q_{C, \text { out }}\right)$ and unburned $\left(Q_{u n C, \text { out }}\right)$ are expressed, respectively, as follows:

$Q_{\text {in }}=\dot{m} \cdot \Delta H_{\text {Fuel }}$

$Q_{C, \text { out }}=\sum\left(F_{j, \text { out }, g}-F_{j, \text { out }, C}\right) \cdot \Delta H_{r x n, j}$

$Q_{u n C, \text { out }}=\sum F_{j, \text { out }, C} \cdot \Delta H_{r x n, j}$

where $\dot{m}$ is the charcoal feeding rate $\left(\mathrm{g} \mathrm{s}^{-1}\right) ; \Delta H_{\text {Fuel }}$ denotes the higher heating value $\left(\mathrm{MJ} \mathrm{kg}^{-1}\right)$ of charcoal; $F_{j, o u t, g}$ and $F_{j, \text { out }, C}$ are the molar flowrate of combustible species $j$ in the effluent stream such as $\mathrm{CO}, \mathrm{CH}_{4}, \mathrm{H}_{2}$, and $\mathrm{C}$; the combustible species generated from charcoal gasification and combustion are denoted as $g$ and $C ; \Delta H_{r x n, j}$ denotes the heat of combustion of species $j$. The output processing capacity for charcoal gasification $\left(Q_{g, \text { out }}\right)$ was calculated by the heat balance, as described by Eq. (30):

$Q_{\text {in }}=Q_{g, \text { out }}+Q_{C, \text { out }}+Q_{u n C, \text { out }}$

As revealed in Fig. 13, $Q_{g, \text { out }}$ for the combustion of charcoal with $\mathrm{Fe}_{2} \mathrm{O}_{3} / \mathrm{Al}_{2} \mathrm{O}_{3}$ and $\mathrm{Fe}_{2} \mathrm{O}_{3} / \mathrm{Al}_{2} \mathrm{O}_{3} / \mathrm{TiO}_{2}$ oxygen 


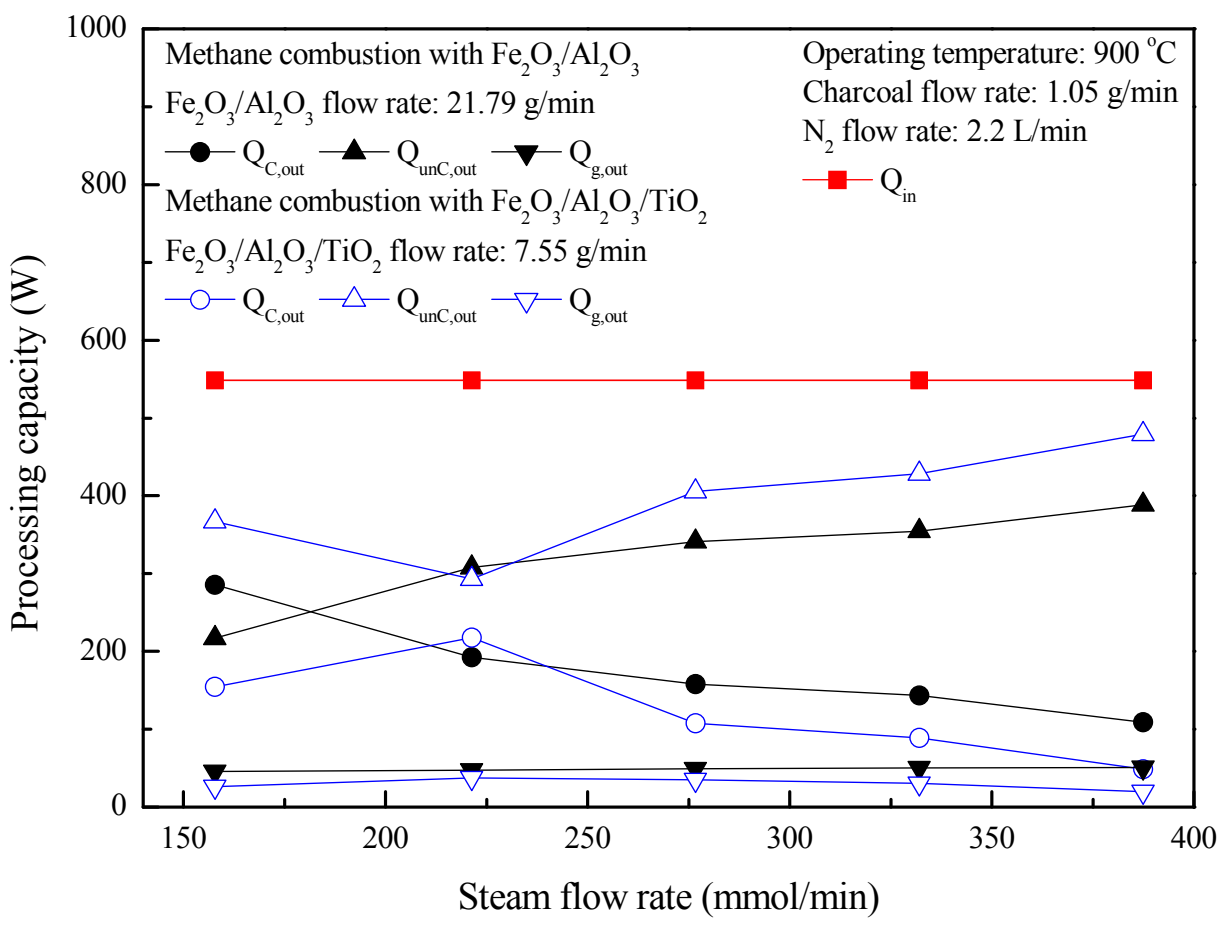

Fig. 13. Effect of steam flow rate on processing capacity for charcoal combustion in the moving bed.

carriers were determined to be roughly $49 \mathrm{~W}$ and $30 \mathrm{~W}$, respectively, further demonstrating that roughly $9 \%$ and $5 \%$ of $Q_{i n}$ released for full charcoal decomposition in the ADMBR. A maximum value of output processing capacity for charcoal combustion with $\mathrm{Fe}_{2} \mathrm{O}_{3} / \mathrm{Al}_{2} \mathrm{O}_{3}$ oxygen carriers was estimated to be $285 \mathrm{~W}$ as $\mathrm{CO}_{2}$ concentration reached nearly $100 \%$. Afterward, $Q_{C \text {,out }}$ was gradually decreased with the increase of steam feeding rate. Moreover, $Q_{C \text {,out }}$ of charcoal combustion by $\mathrm{Fe}_{2} \mathrm{O}_{3} / \mathrm{Al}_{2} \mathrm{O}_{3} / \mathrm{TiO}_{2}$ oxygen carriers increased as steam feeding rate increased from 157.7 to

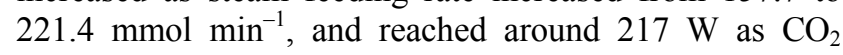
concentration reached 99\%, as shown in Fig. 13. However, $Q_{C, \text { out }}$ decreased obviously with increasing inlet steam flow rate and reduced to around $49 \mathrm{~W}$, indicating that the excessive amount of steam might be negative for burning the charcoal with iron-based oxygen carriers. The heat release of charcoal combustion using the $\mathrm{Fe}_{2} \mathrm{O}_{3} / \mathrm{Al}_{2} \mathrm{O}_{3}$ particles was more than that of using the $\mathrm{Fe}_{2} \mathrm{O}_{3} / \mathrm{Al}_{2} \mathrm{O}_{3} / \mathrm{TiO}_{2}$ particles because the high feeding rate of $\mathrm{Fe}_{2} \mathrm{O}_{3} / \mathrm{Al}_{2} \mathrm{O}_{3}$ was provided. It should be pointed out that although the oxygen carrier flow rate of $\mathrm{Fe}_{2} \mathrm{O}_{3} / \mathrm{Al}_{2} \mathrm{O}_{3} / \mathrm{TiO}_{2}$ only operated at $7.55 \mathrm{~g} \mathrm{~min}^{-1}$, practically $255 \mathrm{~W}$ (about $46 \%$ of $Q_{i n}$ ) was released for the combustion of charcoal by using $\mathrm{Fe}_{2} \mathrm{O}_{3} / \mathrm{Al}_{2} \mathrm{O}_{3} / \mathrm{TiO}_{2}$, probably because combustible gases were more ready to react with the $\mathrm{Fe}_{2} \mathrm{O}_{3}$ contained in the $\mathrm{Fe}_{2} \mathrm{O}_{3} / \mathrm{Al}_{2} \mathrm{O}_{3} / \mathrm{TiO}_{2}$ oxygen carriers.

\section{CONCLUSIONS}

$\mathrm{Fe}_{2} \mathrm{O}_{3}$ supported by $\mathrm{Al}_{2} \mathrm{O}_{3}$ and $\mathrm{Al}_{2} \mathrm{O}_{3} / \mathrm{TiO}_{2}$ was investigated as an oxygen carrier for the CLC of charcoal. The kinetics of reducing $\mathrm{Fe}_{2} \mathrm{O}_{3} / \mathrm{Al}_{2} \mathrm{O}_{3}$ and $\mathrm{Fe}_{2} \mathrm{O}_{3} / \mathrm{Al}_{2} \mathrm{O}_{3} / \mathrm{TiO}_{2}$ with hydrogen were well described by a shrinking core model. The results indicated that the $\mathrm{Fe}_{2} \mathrm{O}_{3} / \mathrm{Al}_{2} \mathrm{O}_{3} / \mathrm{TiO}_{2}$ was reduced more quickly than the $\mathrm{Fe}_{2} \mathrm{O}_{3} / \mathrm{Al}_{2} \mathrm{O}_{3}$ by carbon monoxide, which diffused more easily through the product layer of the former. When the inlet steam flow rate was set to $221.4 \mathrm{mmol} \mathrm{min}^{-1}$, approximately $61.8 \%$ and $47.2 \%$ of the charcoal was combusted in the moving bed reactor with $\mathrm{Fe}_{2} \mathrm{O}_{3} / \mathrm{Al}_{2} \mathrm{O}_{3}$ and $\mathrm{Fe}_{2} \mathrm{O}_{3} / \mathrm{Al}_{2} \mathrm{O}_{3} / \mathrm{TiO}_{2}$, respectively; additionally, these oxygen carriers achieved conversion rates of $29.2 \%$ and $\sim 72.5 \%$, respectively. Based on the XRD characterization, a phase transformation from $\mathrm{Fe}_{2} \mathrm{O}_{3}$ (rhombohedral) and/or $\mathrm{Fe}_{2} \mathrm{TiO}_{5}$ (orthorhombic) to $\mathrm{Fe}_{3} \mathrm{O}_{4}$ (cubic) and $\mathrm{Al}_{2} \mathrm{FeO}_{4}$ (cubic) occurred during the $\mathrm{CLC}$ of charcoal. Because a high flow rate was used for $\mathrm{Fe}_{2} \mathrm{O}_{3} / \mathrm{Al}_{2} \mathrm{O}_{3}$, more heat was released when the charcoal was combusted with this oxygen carrier than with $\mathrm{Fe}_{2} \mathrm{O}_{3} / \mathrm{Al}_{2} \mathrm{O}_{3} / \mathrm{TiO}_{2}$. Furthermore, the $\mathrm{Fe}_{2} \mathrm{O}_{3} / \mathrm{Al}_{2} \mathrm{O}_{3} \mathrm{TiO}_{2}$ particles reacted strongly to syngas $\left(\mathrm{CO}-\mathrm{H}_{2}\right)$ due to their abundant $\mathrm{Fe}_{2} \mathrm{O}_{3}$ content; hence, less $\mathrm{Fe}_{2} \mathrm{O}_{3} / \mathrm{Al}_{2} \mathrm{O}_{3} / \mathrm{TiO}_{2}$ was needed for combusting the charcoal.

\section{ACKNOWLEDGMENTS}

The authors would like to thank the Ministry of Science and Technology of the Republic of China (Taiwan) for financially supporting this research under Contract No. MOST 106-3113-E-007-002-. The contribution on the supply of hematite powders by China Steel Corp. is gratefully acknowledged.

\section{REFERENCES}

Abad, A., Adánez, J., García-Labiano, F., de Diego, L.F., Gayán, P. and Celaya, J. (2007). Mapping of the range of operational conditions for $\mathrm{Cu}-$, Fe-, and Ni-based 
oxygen carriers in chemical-looping combustion. Chem. Eng. Sci. 62: 533-549.

Abad, A., Adánez, J., Cuadrat, A., García-Labiano, F., Gayán, P. and de Diego, L.F. (2011). Kinetics of redox reactions of ilmenite for chemical-looping combustion. Chem. Eng. Sci. 66: 689-702.

Abad, A., García-Labiano, F., Gayán, P., de Diego, L.F. and Adánez, J. (2015). Redox kinetics of $\mathrm{CaMg}_{0.1} \mathrm{Ti}_{0.125} \mathrm{Mn}_{0.775} \mathrm{O}_{2.9-\delta}$ for Chemical Looping Combustion (CLC) and Chemical Looping with Oxygen Uncoupling (CLOU). Chem. Eng. J. 269: 67-81.

Adánez, J., Cuadrat, A., Abad, A., Gayán, P., de Diego, L.F. and García-Labiano, F. (2010). Ilmenite activation during consecutive redox cycles in chemical-looping combustion. Energy Fuels 24: 1402-1413.

Adánez, J, Abad, A, Garcia-Labiano, F, Gayan, P and de Diego, L.F. (2012). Progress in chemical-looping combustion and reforming technologies. Prog. Energy Combust. Sci. 38: 215-282.

Bayham, S.C., Kim, H.R., Wang, D., Tong, A., Zeng, L., McGiveron, O., Kathe, M.V., Chung, E., Wang, W., Wang, A., Majumder, A. and Fan, L.S. (2013). Ironbased coal direct chemical looping combustion process: $200-\mathrm{h}$ continuous operation of a $25-\mathrm{kW}_{\text {th }}$ subpilot unit. Energy Fuels 27: 1347-1356.

Berguerand, N. and Lyngfelt, A. (2008). Design and operation of a $10 \mathrm{~kW}_{\text {th }}$ chemical-looping combustor for solid fuels - testing with South African coal. Fuel 87: 2713-2726.

Breault, R.W., Yarrington, C.S. and Weber, J.M. (2016). The effect of thermal treatment of hematite ore for chemical looping combustion of methane. J. Energy Resour. Technol. 138: 0422021-0422028.

Cabello, A., Abad, A., García-Labiano, F., Gayán, P., de Diego, L.F. and Adánez, J. (2014). Kinetic determination of a highly reactive impregnated $\mathrm{Fe}_{2} \mathrm{O}_{3} / \mathrm{Al}_{2} \mathrm{O}_{3}$ oxygen carrier for use in gas-fueled chemical looping combustion. Chem. Eng. J. 258: 265-280.

Cao, Y., Sit, S.P. and Pan, W.P. (2014). Preparation and characterization of lanthanum-promoted copper-based oxygen carriers for chemical looping combustion process. Aerosol Air Qual. Res. 14: 572-584.

Chiu, P.C. and Ku, Y. (2012). Chemical looping process-a novel technology for inherent $\mathrm{CO}_{2}$ capture. Aerosol Air Qual. Res. 12: 1421-1432.

Chiu, P.C., Ku, Y., Wu, Y.L., Wu, H.C., Kuo, Y.L. and Tseng, Y.H. (2014a). Characterization and evaluation of prepared $\mathrm{Fe}_{2} \mathrm{O}_{3} / \mathrm{Al}_{2} \mathrm{O}_{3}$ oxygen carriers for chemical looping process. Aerosol Air Qual. Res. 14: 981-990.

Chiu, P.C., Ku, Y., Wu, H.C., Kuo, Y.L. and Tseng, Y.H. (2014b). Spent isopropanol solution as possible liquid fuel for moving bed reactor in chemical looping combustion. Energy Fuels 28: 657-665.

Cuadrat, A., Abad, A., García-Labiano, F., Gayán, P., de Diego, L.F. and Adánez, J. (2011). The use of ilmenite as oxygen-carrier in a $500 \mathrm{Wth}$ chemical-looping coal combustion unit. Int. J. Greenhouse Gas Control 5: 1630-1642.

de Diego, L.F., Abad, A., Cabello, A., Gayán, P., García-
Labiano, F. and Adánez, J. (2014) Reduction and oxidation kinetics of a $\mathrm{CaMn}_{0.9} \mathrm{Mg}_{0.1} \mathrm{O}_{3-\delta}$ oxygen carrier for chemical-looping combustion. Ind. Eng. Chem. Res. 53: 87-103.

Dharanipragada, N.V.R.A., Galvita, V.V., Poelman, H., Buelens, L.C. and Marin, G.B. (2017). Insight in kinetics from pre-edge features using time resolved in situ XAS. AlChE J. 64: 1339-1349.

Fan, L.S. (2010). Chemical looping systems for fossil energy conversions. John Wiley \& Sons, Inc., New York.

Fan, L.S., Zeng, L. and Luo, S. (2015). Chemical-looping technology platform. AIChE J. 61: 2-22.

Frick, V., Rydén, M. and Leion, H. (2016). Investigation of $\mathrm{Cu}-\mathrm{Fe}$ and $\mathrm{Mn}-\mathrm{Ni}$ oxides as oxygen carriers for chemical-looping combustion. Fuel Process. Technol. 150: 30-40.

Gao, Z.F., Wu, Z.J. and Liu, W.M. (2016). Preparation and chemical looping combustion properties of $\mathrm{Fe}_{2} \mathrm{O}_{3} / \mathrm{Al}_{2} \mathrm{O}_{3}$ derived from metallurgy iron-bearing dust. J. Environ. Chem. Eng. 4: 1653-1663.

Gayán, P., Forero, C.R., de Diego, L.F., Abad, A., GarcíaLabiano, F. and Adánez, J. (2010). Effect of gas composition in chemical-looping combustion with copper-based oxygen carriers: Fate of light hydrocarbons. Int. J. Greenhouse Gas Control 4: 13-22.

Gu, H., Shen, L., Xiao, J., Zhang, S. and Song, T. (2011). Chemical looping combustion of biomass/coal with natural iron ore as oxygen carrier in a continuous reactor. Energy Fuels 25: 446-455.

Gu, H., Shen, L., Zhong, Z., Niu, X., Ge, H., Zhou, Y. and Xiao, S. (2014). Potassium-modified iron ore as oxygen carrier for coal chemical looping combustion: Continuous test in $1 \mathrm{~kW}$ reactor. Ind. Eng. Chem. Res. 53: 1300613015.

Gucho, E.M., Shahzad, K., Bramer, E.A., Akhtar, N.A. and Brem, G. (2015). Experimental study on dry torrefaction of beech wood and miscanthus. Energies 8: 3903-3923.

Huang, Z., Zhang, Y., Fu, J., Yu, L., Chen, M., Liu, S., He, F., Chen, D., Wei, G., Zhao, K., Zheng, A., Zhao, Z. and Li, H. (2016). Chemical looping gasification of biomass char using iron ore as an oxygen carrier. Int. J. Hydrogen Energy 41: 17871-17883.

International Energy Agency (IEA) (2009). Coal Information 2009 Edition Documentation for Beyond 2020 Files. IEA, Paris, France.

Ishida, M., Takeshita, K., Suzuki, K. and Ohba, T. (2005). Application of $\mathrm{Fe}_{2} \mathrm{O}_{3}-\mathrm{Al}_{2} \mathrm{O}_{3}$ composite particles as solid looping material of the chemical-loop combustor. Energy Fuels 19: 2514-2518.

Ismail, M., Liu, W. and Scott, S.A. (2013). The performance of $\mathrm{Fe}_{2} \mathrm{O}_{3}-\mathrm{CaO}$ oxygen carriers and the interaction of iron oxides with $\mathrm{CaO}$ during chemical looping combustion and $\mathrm{H}_{2}$ production. Energy Procedia 63: 87-97.

Kim, H.R., Wang, D., Zeng, L., Bayham, S., Tong, A., Chung, E., Kathe, M.V., Luo, S., McGiveron, O., Wang, A., Sun, Z., Chen, D. and Fan, L.S. (2013). Coal direct chemical looping combustion process: Design and operation of a 25-kW th sub-pilot unit. Fuel 108: 370-384. 
Ksepko, E., Babinski, P., Evdou, A. and Nalbandian, L. (2016). Studies on the redox reaction kinetics of selected, naturally occurring oxygen carrier. J. Therm. Anal. Calorim. 124: 137-150.

Ksepko, E., Babinski, P. and Nalbandian, L. (2017). The redox reaction kinetics of Sinai ore for chemical looping combustion applications. Appl. Energy 190: 1258-1274.

$\mathrm{Ku}, \mathrm{Y} ., \mathrm{Wu}, \mathrm{H} . \mathrm{C}$., Chiu, P.C., Tseng, Y.H. and Kuo, Y.L. (2014). Methane combustion by moving bed fuel reactor with $\mathrm{Fe}_{2} \mathrm{O}_{3} / \mathrm{Al}_{2} \mathrm{O}_{3}$ oxygen carriers. Appl. Energy 113: 1909-1915.

Ku, Y., Lin, P.H., Wu, H.C., Liu, Y.C., Tseng, Y.H. and Lee, H.Y. (2017). Preparation of $\mathrm{Fe}_{2} \mathrm{O}_{3} / \mathrm{Al}_{2} \mathrm{O}_{3}$ and $\mathrm{Fe}_{2} \mathrm{O}_{3} / \mathrm{TiO}_{2}$ pellets as oxygen carrier for chemical looping process. Aerosol Air Qual. Res. 17: 2300-2309.

Kuo, Y.L., Huang, W.C., Hsu, W.M., Tseng, Y.H. and Ku, Y. (2015). Use of spinel nickel aluminum ferrite as selfsupported oxygen carrier for chemical looping hydrogen generation process. Aerosol Air Qual. Res. 15: 27002708.

Leion, H., Lyngfelt, A., Johansson, M., Jerndal, E. and Mattisson, T. (2008). The use of ilmenite as an oxygen carrier in chemical-looping combustion. Chem. Eng. Res. Des. 86: 1017-1026.

Li, F., Luo, S., Sun, Z., Bao, X. and Fan, L.S. (2011). Role of metal oxide support in redox reactions of iron oxide for chemical looping applications: Experiments and density functional theory calculations. Energy Environ. Sci. 4: 3661-3667.

Linderholm, C. and Schmitz, M. (2016). Chemical-looping combustion of solid fuels in a $100 \mathrm{~kW}$ dual circulating fluidized bed system using iron ore as oxygen carrier. J. Environ. Chem. Eng. 4: 1029-1039.

Liu, Y.C., Ku, Y., Tseng, Y.H., Lee, H.Y. and Kuo, Y.L. (2016). Fabrication of $\mathrm{Fe}_{2} \mathrm{O}_{3} / \mathrm{TiO}_{2}$ oxygen carriers for chemical looping combustion and hydrogen generation. Aerosol Air Qual. Res. 16: 2023-2032.

Luo, M., Wang, S., Wang, L. and Lv, M. (2014a). Reduction kinetics of iron-based oxygen carriers using methane for chemical-looping combustion. J. Power Sources 270: 434-440.

Luo, S., Bayham, S., Zeng, L., McGiveron, O., Chung, E., Majumder, A. and Fan, L.S. (2014b). Conversion of metallurgical coke and coal using a coal direct chemical looping (CDCL) moving bed reactor. Appl. Energy 118: 300-308.

Luo, S., Zeng, L. and Fan, L.S. (2015). Chemical looping technology: oxygen carrier characteristics. Annu. Rev. Chem. Biomol. Eng. 6: 53-75.

Markström, P. and Lyngfelt, A. (2012). Designing and operating a cold-flow model of a $100 \mathrm{~kW}$ chemicallooping combustor. Powder Technol. 222: 182-192.

Markström, P., Linderholm, C. and Lyngfelt, A. (2013). Chemical-looping combustion of solid fuels - design and operation of a $100 \mathrm{~kW}$ unit with bituminous coal. Int. J. Greenhouse Gas Control 15: 150-162.

Mattisson, T., Johansson, M. and Lyngfelt, A. (2004). Multicycle reduction and oxidation of iron oxide particles-application to chemical-looping combustion.
Energy Fuels 18: 628-637.

Mendiara, T., Abad, A., de Diego, L.F., García-Labiano, F., Gayán, P. and Adánez, J. (2013). Biomass combustion in a CLC system using an iron ore as an oxygen carrier. Int. J. Greenhouse Gas Control 19: 322-330.

Mendiara, T., de Diego, L.F., García-Labiano, F., Gayán, P., Abad, A. and Adánez, J. (2014). On the use of a highly reactive iron ore in chemical looping combustion of different coals. Fuel 126: 239-249.

Moghtaderi, B. and Song, H. (2010). Reduction properties of physically mixed metallic oxide oxygen carriers in chemical looping combustion. Energy Fuels 24: 53595368.

Monazam, E.R., Breault, R.W., Siriwardane, R. and Miller, D.D. (2013). Thermogravimetric analysis of modified hematite by methane $\left(\mathrm{CH}_{4}\right)$ for chemical-looping combustion: A global kinetics mechanism. Ind. Eng. Chem. Res. 52: 14808-14816.

Qin, W., Wang, Y., Dong, C., Zhang, J., Chen, Q. and Yang, Y. (2013). The synergetic effect of metal oxide support on $\mathrm{Fe}_{2} \mathrm{O}_{3}$ for chemical looping combustion: a theoretical study. Appl. Surf. Sci. 282: 718-723.

Shen, L., Wu, J., Xiao, J., Song, Q. and Xiao, R. (2009). Chemical-looping combustion of biomass in a $10 \mathrm{~kW}_{\text {th }}$ reactor with iron oxide as an oxygen carrier. Energy Fuels 23: 2498-2505.

Song, T., Shen, L., Zhang, H., Gu, H., Zhang, S. and Xiao, J. (2012). Chemical Looping Combustion of Two Bituminous Coal/Char with Natural Hematite as Oxygen Carrier in $1 \mathrm{~kW}_{\text {th }}$ Reactor, Proc. 2nd Int. Conf. on Chemical Looping, Darmstadt, Germany.

Sozinho, T., Pelletant, W., Stainton, H., Guillou, F. and Gauthier, T. (2012). Main Results of the $10 \mathrm{~kW}_{\text {th }}$ Pilot Plant Operation, Proc. 2nd Int. Conf. on Chemical Looping, Darmstadt, Germany.

Strandberg, M., Olofsson, I., Pommer, L., WiklundLindström, S., Åberg, K. and Nordin, A. (2015). Effects of temperature and residence time on continuous torrefaction of spruce wood. Fuel Process. Technol. 134: 387-398.

Ströhle, J., Orth, M. and Epple, B. (2015). Chemical looping combustion of hard coal in a $1 \mathrm{MW}_{\text {th }}$ pilot plant using ilmenite as oxygen carrier. Appl. Energy 157: 288-294.

Sun, Z., Lu, D.Y., Ridha, F.N., Hughes, R.W. and Filippou, D. (2017). Enhanced performance of ilmenite modified by $\mathrm{CeO}_{2}, \mathrm{ZrO}_{2}, \mathrm{NiO}$, and $\mathrm{Mn}_{2} \mathrm{O}_{3}$ as oxygen carriers in chemical looping combustion. Appl. Energy 195: 303-315.

Thon, A., Kramp, M., Hartge, E.U., Heinrich, S. and Werther, J. (2014). Operational experience with a system of coupled fluidized beds for chemical looping combustion of solid fuels using ilmenite as oxygen carrier. Appl. Energy 118: 309-317.

U.S. Energy Information Administration (EIA) (2017). Monthly energy review: August 2017, EIA, U.S. Department of Energy, Washington, DC, USA.

Wang, W., Zhang, B., Wang, G. and Li, Y. (2016). $\mathrm{O}_{2}$ release of Mn-based oxygen carrier for chemical looping 
air separation (CLAS): An insight into kinetic studies. Aerosol Air Qual. Res. 16: 453-463.

World Energy Council (WEC) (2016). World Energy Resources 2016, World Energy Council, London, UK.

Wu, H.C., Ku, Y., Tsai, H.H., Kuo, Y.L. and Tseng, Y.H. (2015). Rice husk as solid fuel for chemical looping combustion in an annular dual-tube moving bed reactor. Chem. Eng. J. 280: 82-89.

Wu, H.C. and $\mathrm{Ku}$, Y. (2016). Chemical looping gasification of charcoal with iron-based oxygen carriers in an annular dual-tube moving bed reactor. Aerosol Air Qual. Res. 16: 1093-1103.

Zafar, Q., Mattisson, T. and Gevert, B. (2006). Redox investigation of some oxides of transition-state metals $\mathrm{Ni}, \mathrm{Cu}, \mathrm{Fe}$, and supported on $\mathrm{SiO}_{2}$ and $\mathrm{MgAl}_{2} \mathrm{O}_{4}$.
Energy Fuels 20: 33-44.

Zhou, Z., Han, L. and Bollas, G.M. (2014). Overview of chemical-looping reduction in fixed bed and fluidized bed reactors focused on oxygen carrier utilization and reactor efficiency. Aerosol Air Qual. Res. 14: 559-571.

Zhu, W., Winterstein, J., Maimon, I., Yin, Q., Yuan, L., Kolmogorov, A.N., Sharma, R. and Zhou, G. (2016). Atomic structural evolution during the reduction of $\alpha$ $\mathrm{Fe}_{2} \mathrm{O}_{3}$ nanowires. J. Phys. Chem. C 120: 14854-14862.

Received for review, August 18, 2018

Revised, April 28, 2019

Accepted, June 19, 2019 